\title{
Article \\ Development of Polypyrrole Modified Screen-Printed Carbon Electrode Based Sensors for Determination of L-Tyrosine in Pharmaceutical Products
}

\author{
Ancuța Dinu (D) and Constantin Apetrei *(D) \\ Faculty of Science and Environment, “Dunărea de Jos” University of Galati, 800008 Galati, Romania; \\ ancuta.dinu@ugal.ro \\ * Correspondence: apetreic@ugal.ro; Tel.: +40-727-580-914
}

Citation: Dinu, A.; Apetrei, C. Development of Polypyrrole

Modified Screen-Printed Carbon

Electrode Based Sensors for Determination of L-Tyrosine in Pharmaceutical Products. Int. J. Mol. Sci. 2021, 22, 7528. https://doi.org/ $10.3390 /$ ijms 22147528

Academic Editor: Maciej Jarzębski

Received: 15 June 2021

Accepted: 13 July 2021

Published: 14 July 2021

Publisher's Note: MDPI stays neutral with regard to jurisdictional claims in published maps and institutional affiliations.

Copyright: (c) 2021 by the authors. Licensee MDPI, Basel, Switzerland. This article is an open access article distributed under the terms and conditions of the Creative Commons Attribution (CC BY) license (https:// creativecommons.org/licenses/by/ $4.0 /)$.

\begin{abstract}
Good health, of vital importance in order to carry out our daily routine, consists of both physical and mental health. Tyrosine (Tyr) deficiency as well as its excess are issues that can affect mental health and can generate disorders such as depression, anxiety, or stress. Tyr is the amino acid (AA) responsible for maintaining good mental health, and for this reason, the present research presents the development of new electrochemical sensors modified with polypyrrole (PPy) doped with different doping agents such as potassium hexacyanoferrate (II) (FeCN), sodium nitroprusside (NP), and sodium dodecyl sulfate (SDS) for a selective and sensitive detection of Tyr. The development of the sensors was carried out by chronoamperometry (CA) and the electrochemical characterization was carried out by cyclic voltammetry (CV). The detection limits (LOD) obtained with each modified sensor were $8.2 \times 10^{-8} \mathrm{M}$ in the case of PPy /FeCN-SPCE, $4.3 \times 10^{-7} \mathrm{M}$ in the case of PPy/NP-SPCE, and of $3.51 \times 10^{-7} \mathrm{M}$ in the case of PPy/SDS-SPCE, thus demonstrating a good sensitivity of these sensors detecting L-Tyr. The validation of sensors was carried out through quantification of L-Tyr from three pharmaceutical products by the standard addition method with recoveries in the range 99.92-103.97\%. Thus, the sensors present adequate selectivity and can be used in the pharmaceutical and medical fields.
\end{abstract}

Keywords: L-Tyrosine; polypyrrole; sensor; amino acid; cyclic voltammetry; chronoamperometry

\section{Introduction}

We live in times with a lot of restrictive measures meant to stop the spread of severe acute respiratory syndrome-coronavirus (SARS-CoV-2), and numerous papers published by experts in psychology as well as medicine draw attention to the fact that the isolation and quarantine have affected everyone and have led to an increase in the number of depression, emotional disorders, anxiety, and sleep issues [1-3]. The negative effects that affect the health of the individual caused by the new coronavirus can be partially or completely treated with pharmaceuticals containing a compound, which acts on the central nervous system, namely tyrosine (Tyr), the target compound of this study. Tyr is a chemical compound discovered in 1846 by German chemist Justus von Liebig, an important compound for a healthy nervous system as it is the precursor of the main neurotransmitters, respectively dopamine, adrenaline, and noradrenaline [4,5]. Low levels of Tyr in human bodies can lead to diseases such as albinism and alkaptonuria whereas high levels of Tyr can lead to different emotional disorders, fits of depression, and even Parkinson's disease [6-8]. On the other hand, Tyr is also an important AA for herbivores, being a basic element of proteins $[9,10]$.

For the human body, Tyr is a non-essential AA synthesized in the liver through the conversion of the essential AA phenylalanine (Phe), according to Figure 1, but it can also be assimilated through external sources by including in the diet foods such as dairy products, meat, fish, eggs, walnuts, beans, oatmeal, and wheat [11,12]. In addition, Tyr is 
a compound that can be found in many pharmaceutical supplements aimed to help with inborn disorders of metabolism known as phenylketonuria (PKU) [13-15].

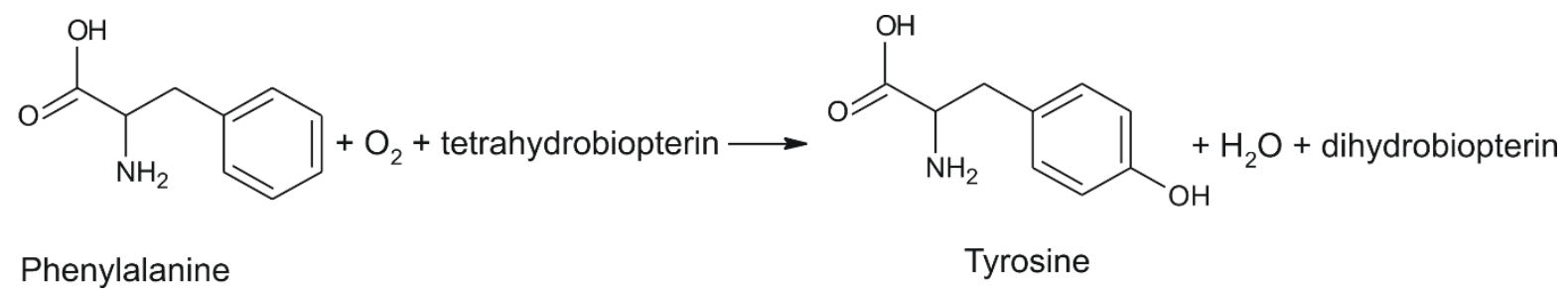

Figure 1. Conversion of Phe in Tyr (adapted from [16]).

On the other hand, Tyr, together with zinc, magnesium, manganese, and iodine helps to improve the role of the thyroid gland, reducing disorders such as ponderal gain, edema, muscular spasms as well as brittle hair and nails $[17,18]$.

In the literature, there are a number of methods used to determine Tyr in both human fluids and pharmaceutical products, and in this research study is presented the development of novel sensors for a faster, easier, and sensitive detection of this AA [12,19-22]. Many of the classical methods used to detect Tyr are sensitive and selective but require expensive equipment and a difficult and long processing technique such as liquid chromatographymass spectrometry (LC-MS) [23], high-performance liquid chromatography (HPLC) with ultraviolet (UV) detection [24], chemiluminescence [25], fluorimetry [26], and capillary electrophoresis [27].

However, in recent years, faster and cheaper detection methods have been developed with high precision and sensitivity based on electroanalytical methods using potentiometric [28], optical [29], colorimetric [30], or voltamperometric sensors [31-33].

The usual voltamperometric methods used for L-Tyr detection reported in the literature are differential pulse voltammetry [34], cyclic voltammetry [35,36], chronoamperometry [37], linear sweep voltammetry [38,39], and square wave voltammetry [40].

Different sensitive materials could be used for the development of sensors such as PPy, a polymer from the conducting polymers (CPs) class, an important field of research of interest, as in 2000, the Nobel Prize for Chemistry was awarded to three researchers with outstanding results in this field [41]. The synthesis and properties of PPy have been studied since 1916 when hydrogen peroxide was used for the chemical oxidation of pyrrole. PPy was obtained in the form of "black pyrrole" [30,31]. PPy synthesis can also be carried out electrochemically by means of CA, chronopotentiometry, and CV [42-44].

The various practical applicabilities of PPy are due to its numerous useful properties, the most important being its malleability, stability, electrical conductivity, and biocompatibility. These properties make it useful in different fields such as biology, medicine, pharmacy, and chemistry [44]. PPy is one of the most widely used conducting polymers in developing electrochemical sensors and biosensors for different analytes of interest. Regarding PPy usefulness in sensor development, being a conjugated polymer positively charged and doped with different anionic species, it brings a series of benefits such as high current density, fast electron transfer, biocompatibility, easy preparation, air stability, and its capacity to integrate a large variety of ion doping [45].

Following research on PPy and its use in different applicative fields, it was found that certain thermic (stability), electrical (conductivity), and morphological (permeability) PPy properties need improvement [42]. Thus, for PPy chemical synthesis, many researchers have used different oxidants such as ferric chloride $\left(\mathrm{FeCl}_{3}\right)$ or ammonium persulfate. Electrosynthesis and doping with chloride $\left(\mathrm{Cl}^{-}\right)$, sulfate $\left(\mathrm{SO}_{4}{ }^{2-}\right)$, tetrafluoroborate $\left(\mathrm{BF}_{4}{ }^{-}\right)$, and perchlorate $\left(\mathrm{ClO}_{4}{ }^{-}\right)$have also been employed. Few studies have reported PPy doped with sodium dodecyl sulfate (SDS), potassium hexacyanoferrate (II) (FeCN), sodium Nitroprusside (NP), dodecylbenzene sulfonate (DBS), and p-toluene sulfonate (PTS) in different organic solvents or in aqueous environments, which could lead to high performances, 
respectively high conductivity, high thermic stability, reproducibility, etc. [34,35]. One advantage of electrochemical synthesis is the possibility of carrying out the deposition on the electrode and the doping of the polymer in one stage, a procedure useful in the case of electrochemical sensor development [46].

In this research regarding L-Tyr detection, new sensors were developed through the modification of screen-printed carbon electrodes with PPy doped with electroactive and surfactant compounds by the CA method. In the case of electropolymerization, an adequate potential has been applied in order to induct the oxidation reaction in the presence of a doping agent, which can ensure the electroneutrality of the polymeric film [47-49]. All these reasons together determined and led to research regarding the development, characterization, and use of new voltamperometric sensors based on PPy modified screenprinted electrodes, doped with three doping agents in order to detect and quantify with increased sensitivity, selectivity, and reproducibility of the AA L-Tyr present in pharmaceutical products, respectively: PPy/FeCN-SPCE, PPy/DSA-SPCE, and PPy/NP-SPCE. This study is important because such sensors modified with PPy doped with electroactive compounds for the detection of L-tyrosine in pharmaceuticals by electrochemical methods have not been developed so far. The novelty is related to development of sensors for the detection of L-Tyr in complex pharmaceutical samples with appropriate sensitivity and selectivity. Complex pharmaceutical samples are difficult samples to analyze due to a huge number of components and possible interference among these. The analysis of such samples was successful accomplished in this research. The sensor PPy/FeCN-SPCE was validated at the laboratory level and it could be used in routine analysis for the quality control of pharmaceutics.

\section{Materials and Methods}

\subsection{Chemicals and Solutions}

L-Tyr ( $\geq 98 \%$ ), potassium chloride ( $\geq 99.0 \%)(\mathrm{KCl}), \mathrm{FeCN}(\geq 99.5 \%)$, SDS ( $\geq 99.0 \%)$, $\mathrm{NP}(\geq 99 \%)$, pyrrole (98\%), L-tryptophan, L-cysteine, and L-phenylalanine were purchased from Sigma-Aldrich (St. Louis, MO, USA).

The preparation of the solutions of these compounds was performed with ultrapure water $\left(18.3 \mathrm{M} \Omega \times \mathrm{cm}\right.$, Milli-Q Simplicity ${ }^{\circledR}$ Water Purification System from Millipore Corporation, Burlington, MA, USA).

\subsection{Equipment}

The electrode modifications with PPy by the CA method were carried out using the EG\&G potentiostat/galvanostat (Princeton Applied Research, Oak Ridge, TN, USA), 263A model, controlled by ECHEM software. The SPCEs were purchased from MetrohmDropsens (www.dropsens.com) (accessed on 22 April 2021). An Ag/ $\mathrm{AgCl} / \mathrm{KCl}_{3 \mathrm{M}}$ electrode was used as the reference electrode, the counter electrode was a Pt wire, and the working electrode was a screen-printed carbon electrode.

A Biologic SP 150 potentiostat/galvanostat (Bio-Logic Science Instruments SAS, Seyssinet-Pariset, France) was used for the electrochemical measurements and the software used for control and data acquisition was EC-Lab Express. The electrochemical cell used for the analysis of the samples had a capacity of $15 \mathrm{~mL}$ and the reference electrode and the counter electrode were those integrated in the commercial sensor device (counter electrode-carbon, $\mathrm{Ag} / \mathrm{AgCl}$ reference electrode). For the analysis of the experimentally obtained voltammograms, Microsoft Excel software was used.

A JEOL T-300 scanning electron microscope was used for the surface morphology studies. For dissolving and homogenization of all solutions, an Elmasonic $\mathrm{S} 10 \mathrm{H}$ ultrasonic bath was used.

\subsection{Sensor Configuration and Methodology}

For the detection of L-Tyr, screen-printed carbon electrodes purchased from MetrohmDropsens (SPCE-model DRP- C110, diameter of $4 \mathrm{~mm}$, surface of $12.56 \mathrm{~mm}^{2}$ ) were 
modified with PPy. For PPy deposition, three different solutions of monomer/doping agent (FeCN, SDS and NP) 0.1 M/0.1 M were used. An ultrasonic bath was used in order to homogenize the solutions by ultrasonication for $5 \mathrm{~min}$. For SPCE modification, the CA method was used by applying a potential $0.8 \mathrm{~V}$ during $90 \mathrm{~s}$ at a constant temperature of $25^{\circ} \mathrm{C}$. After being manufactured, the sensors were rinsed with ultrapure water and kept in the dark at $4{ }^{\circ} \mathrm{C}$ until use. By modification of the SPCE surface, the following chemically modified sensors were obtained: PPy/FeCN-SPCE, PPy/SDS-SPCE, and PPy/NP-SPCE.

Then, the electrochemical behavior of PPy sensors PPy/FeCN-SPCE, PPy/SDS-SPCE, and PPy/NP-SPCE was analyzed through the CV technique in a solution of $0.1 \mathrm{M}$ of $\mathrm{KCl}$ and then in a double solution containing $10^{-3} \mathrm{M} \mathrm{L}$-Tyr and $0.1 \mathrm{M} \mathrm{KCl}$. In the case of CV, the established parameters were: initial potential $0.0 \mathrm{~V}$, positive vertex potential $0.5 \mathrm{~V}$, negative vertex potential $-1.0 \mathrm{~V}$, and the scan rate was between 0.1 and $1.0 \mathrm{~V} \times \mathrm{s}^{-1}$. For the $\mathrm{CV}$ studies with the polypyrrole based sensors immersed in $\mathrm{KCl}$ and $\mathrm{KCl}+$ Tyr solutions, the screen-printed reference electrode $\mathrm{Ag} / \mathrm{AgCl}$ was used. The counter electrode was a screen-printed C electrode integrated on the commercial electrode DRP-110. Six cycles were recorded in the solution to be analyzed in order to stabilize the sensor signals. All the results reported in this study are after the stabilization stage. Prior to the electrochemical measurements, the electrolyte solution was deoxygenated with nitrogen.

\subsection{Samples Tested}

In order to validate the results obtained with modified electrodes, we selected three pharmaceutical products containing L-Tyr in different concentrations, from three different producers, one of the products containing more AAs. Thus, we analyzed L-Tyrosine (SOLARAY) (500 mg L-tyrosine), Tiroidin (PARAPHARM) (90 mg tyrosine), and Cebrium (EVER NEURO PHARMA) (4.012 mg L-Tyrosine).

Compared to L-Tyrosine $500 \mathrm{mg}$ SOLARAY, which is a product that contains only the amino acid under study, the other two pharmaceuticals also contain other active compounds, in addition to the amino acid L-tyrosine, as follows: Tiroidin PARAPHARMspirulina, vitamin E (alfa-tocoferol), iodine (in the form of potassium iodine), selenium (in the form of sodium selenite), and Cebrium EVER NEURO PHARMA-glutamic acid, lysine, leucine, arginine, aspartic acid, serine, phenylalanine, valine, threonine, tyrosine, isoleucine, histidine, methionine, and tryptophan.

For the electroanalysis of the pharmaceutical products, these were triturated to obtain a homogenous powder. A part of this powder was weighed and dissolved in $0.1 \mathrm{M} \mathrm{KCl}$ solution and ultra-sonicated for $15 \mathrm{~min}$. The unsolved excipients were removed from the solution by filtration. Knowing the amount of L-Tyr in the pharmaceutical products, the amount of solid powder dissolved, and the volume of $\mathrm{KCl}$ solution added, the concentration of L-Tyr was calculated. These solutions, prepared from pharmaceutical products, were used for the validation of the sensor by the standard addition method.

\section{Results and Discussions}

\subsection{Deposition of the PPy on the Surface of SPCEs by Chronoamperometry}

PPy, a CP that offers sensors higher sensitive properties, as previously mentioned, was used to modify SPCEs, the electrosynthesis being achieved in the presence of three doping agents.

The doping agent/monomer solutions were each introduced into the electrochemical cell, the three electrodes were connected, and a potential of $0.8 \mathrm{~V}$ was applied to the working electrode during $90 \mathrm{~s}$. The chronoamperograms obtained for six different sensors developed from the same solution are presented in Figure 2. 

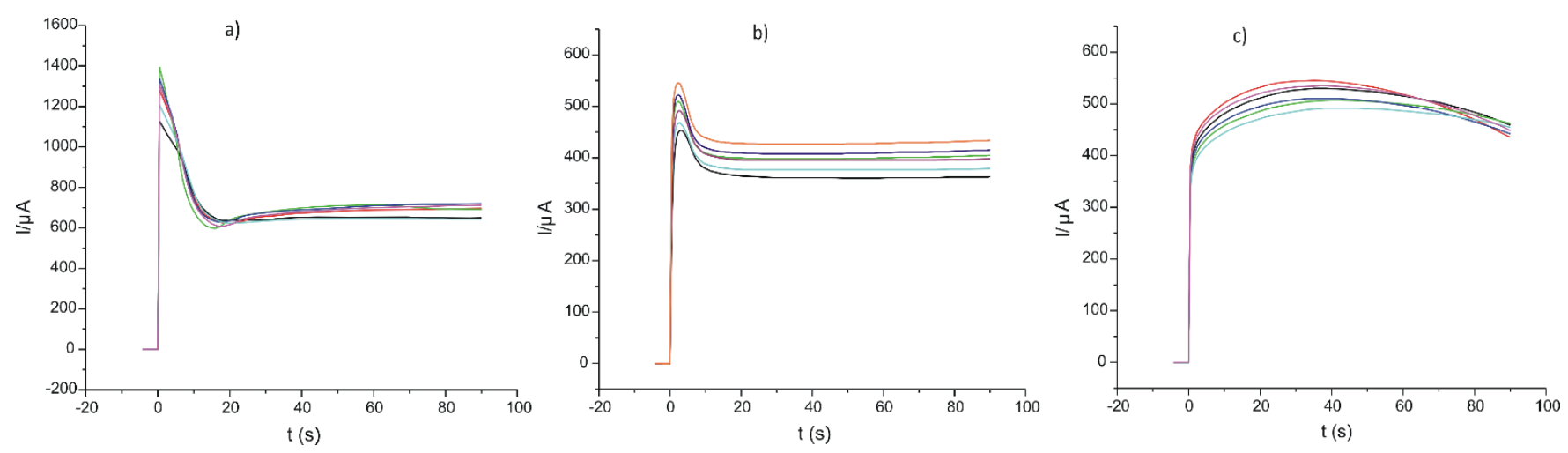

Figure 2. Current versus time curves registered during the electrosynthesis of six different sensors prepared in the same conditions (a) PPy /FeCN, (b) PPy/NP, and (c) PPy/SDS.

As can be observed in Figure 2, the process of electrodeposition is strongly influenced by the physical and chemical properties of the doping agent. The dynamic of the processes was different, the deposition rate being higher in the case of $\mathrm{FeCN}$.

The general PPy electrosynthesis [50] and doping process [51] are shown in Figure 3A,B, respectively.

A.

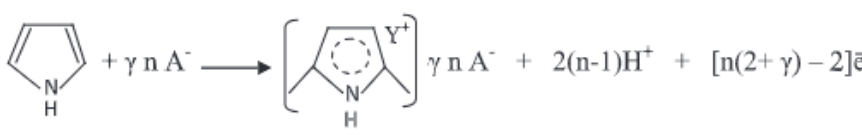

where $\gamma$ is the doping level<smiles>Cc1ccc(-c2ccc(-c3ccc(-c4ccc(-c5ccc(-c6ccc(C)[nH]6)[nH]5)[nH]4)[nH]3)[nH]2)[nH]1</smiles><smiles></smiles>

Figure 3. (A) General reaction of pyrrole electropolymerization (Reprinted from [50] with permission of the publisher); (B) Molecular structure of PPy and general doping process [51].

The doping agents used in this research were selected according to a series of characteristics: electroactivity, multiple charges, and large molecular weight. These characteristics should improve the stability of the sensitive layer as well as the sensitivity and selectivity.

In order to determine the thickness of the polymer layer deposited on the surface of the electrode, the chronoamperograms were presented in the form of electrical charge $(\mathrm{Q})$ as function of time (Figure 4).

Figures 2 and 4 show the chronoamperometric curves corresponding to six sensors prepared from the same solution pyrrole/doping agent in order to verify the reproducibility of the preparation method. As can be seen, the differences between the sensors prepared under the same conditions were very small, the coefficient of variation being less than $5 \%$. 


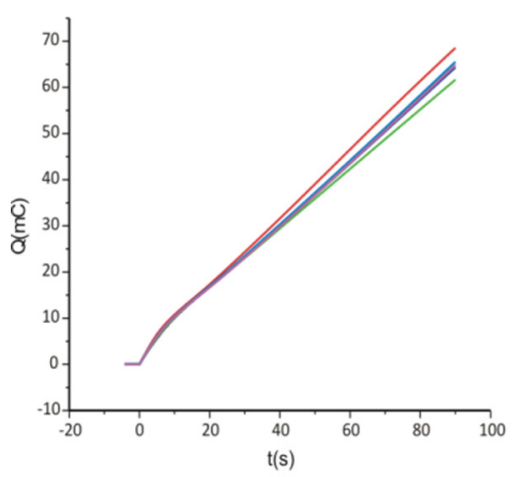

a. $\mathrm{PPy} / \mathrm{FeCN}$

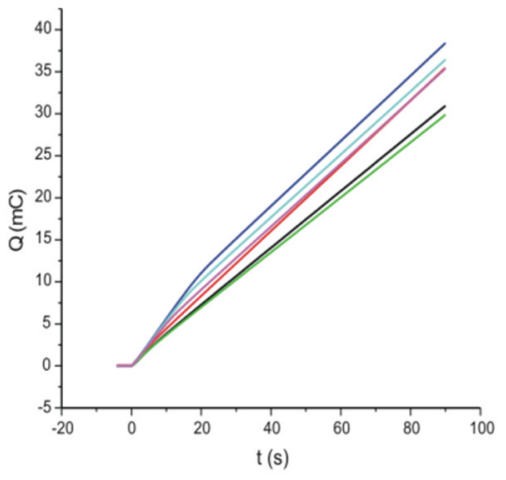

b. $\mathrm{PPy} / \mathrm{NP}$

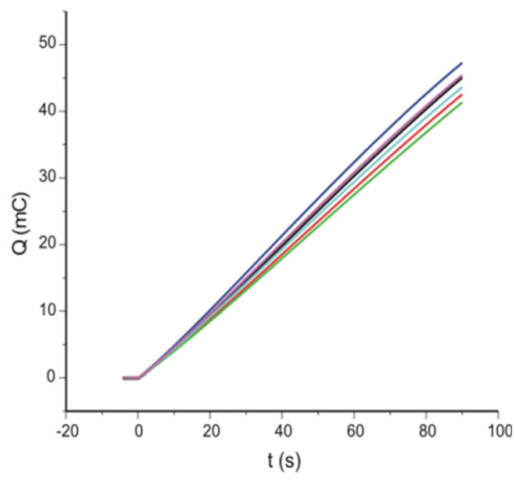

c. PPy/SDS

Figure 4. $Q$ versus time $(t)$ curves registered during electrosynthesis of six different sensors prepared in the same conditions in the presence of (a) FeCN, (b) NP, and (c) SDS.

From the electrochemical charges employed for each electropolymerization, knowing the surface of the electrode $\left(\mathrm{A} / \mathrm{cm}^{2}\right)$, the thickness of the polymer layer deposited on the electrode was calculated, according to Equation (1):

$$
\mathrm{d}=\frac{\mathrm{QM}_{\mathrm{w}}}{\mathrm{zFA} \rho}
$$

where $Q$ is the oxidation charge; $M_{W}$ is the molecular mass of the monomer $(M=67.0892 \mathrm{~g} / \mathrm{mol})$; $\mathrm{z}$ is the number of electrons; $\mathrm{F}$ is the Faraday constant; $\mathrm{A}$ is the surface area of the electrode; and $\rho$ is the polymer density $\left(\rho_{\mathrm{PPy}}=1.5 \mathrm{~g} / \mathrm{cm}^{3}\right)$ [52]. The values obtained are presented in Table 1.

Table 1. The thickness of the polymer films.

\begin{tabular}{cc}
\hline Electrode & Thickness $(\mu \mathrm{m})^{-}$ \\
\hline PPy $/$ FeCN-SPCE $^{1}$ & 0.163 \\
\hline PPy $/$ NP-SPCE $^{2}$ & 0.065 \\
\hline PPy $/$ SDS-SPCE $^{3}$ & 0.077 \\
\hline
\end{tabular}

${ }^{1} \mathrm{PPy} / \mathrm{FeCN}-\mathrm{SPCE}$-polypyrrole/potassium hexacyanoferrate (II)-screen-printed carbon electrode; ${ }^{2} \mathrm{PPy} / \mathrm{NP}$ SPCE—polypyrrole/sodium nitroprusside-screen-printed carbon electrode; ${ }^{3}$ PPy/SDS-SPCE—polypyrrole/ sodium dodecyl sulfate-screen-printed carbon electrode.

As it can be seen from the table, the thickness of the polymer film largely depends on the nature of the doping system and its redox properties. The thickness of the films, in the nanometric range, is optimal for a sensitive detection of L-Tyr. It should be said that thicker PPy films can be achieved in the case of FeCN because this doping agent is more redox active and the electrodeposition kinetics are faster compared to the other doping agents.

The morphology of the polymeric films was studied by scanning electron microscopy and the images obtained are presented in Figure 5.

The polypyrrole films doped with different doping agents showed different morphologies, the polymer being formed mainly from spheres of various sizes. These differences are related to the nature of the doping agent and the different deposition rate of the PPy film. 


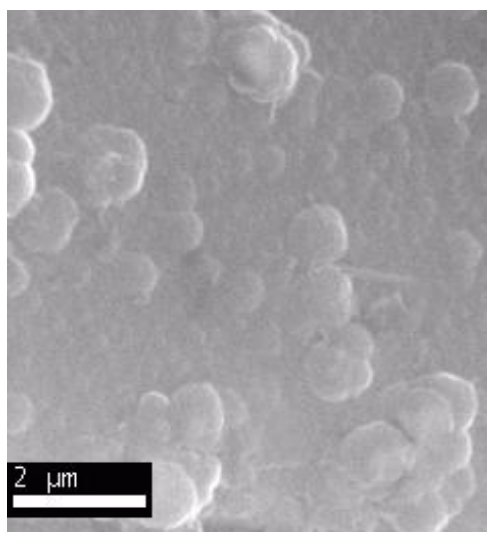

(a)

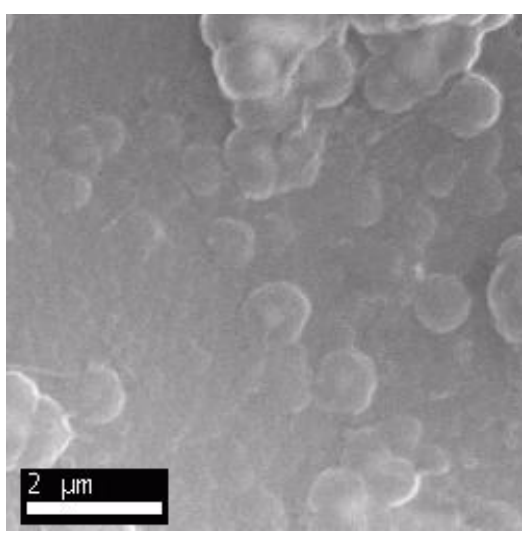

(b)

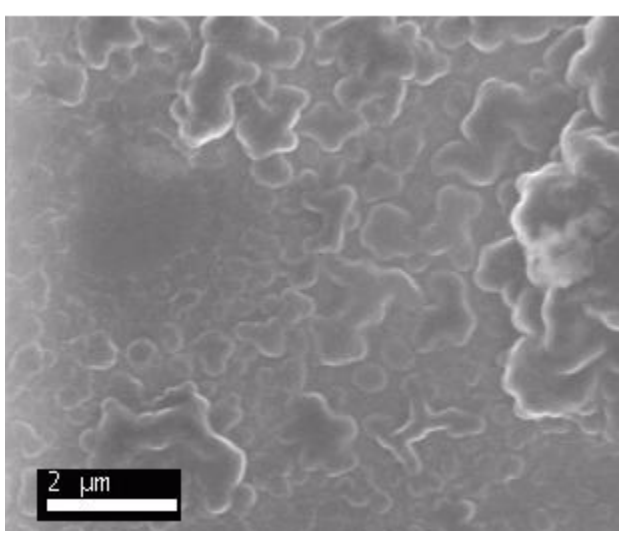

(c)

Figure 5. Scanning electron microscopy images of the sensitive element of polypyrrole based sensors doped with (a) FeCN, (b) NP, and (c) SDS.

\subsection{Voltammetric Responses}

3.2.1. Electrochemical Responses of Sensor Immersed in $0.1 \mathrm{M} \mathrm{KCl}$ Solution and in $0.1 \mathrm{M}$ $\mathrm{KCl}-10^{-3} \mathrm{M}$ L-Tyr Solution before Modification

The electrochemical response of unmodified carbon screen-printed electrodes was investigated in two solutions: $0.1 \mathrm{M} \mathrm{KCl}$ solution, respectively in $0.1 \mathrm{M} \mathrm{KCl}-10^{-3} \mathrm{M} \mathrm{L-Tyr}$ solution (Figure 6) in the potential range from 1.0 to $0.5 \mathrm{~V}$.
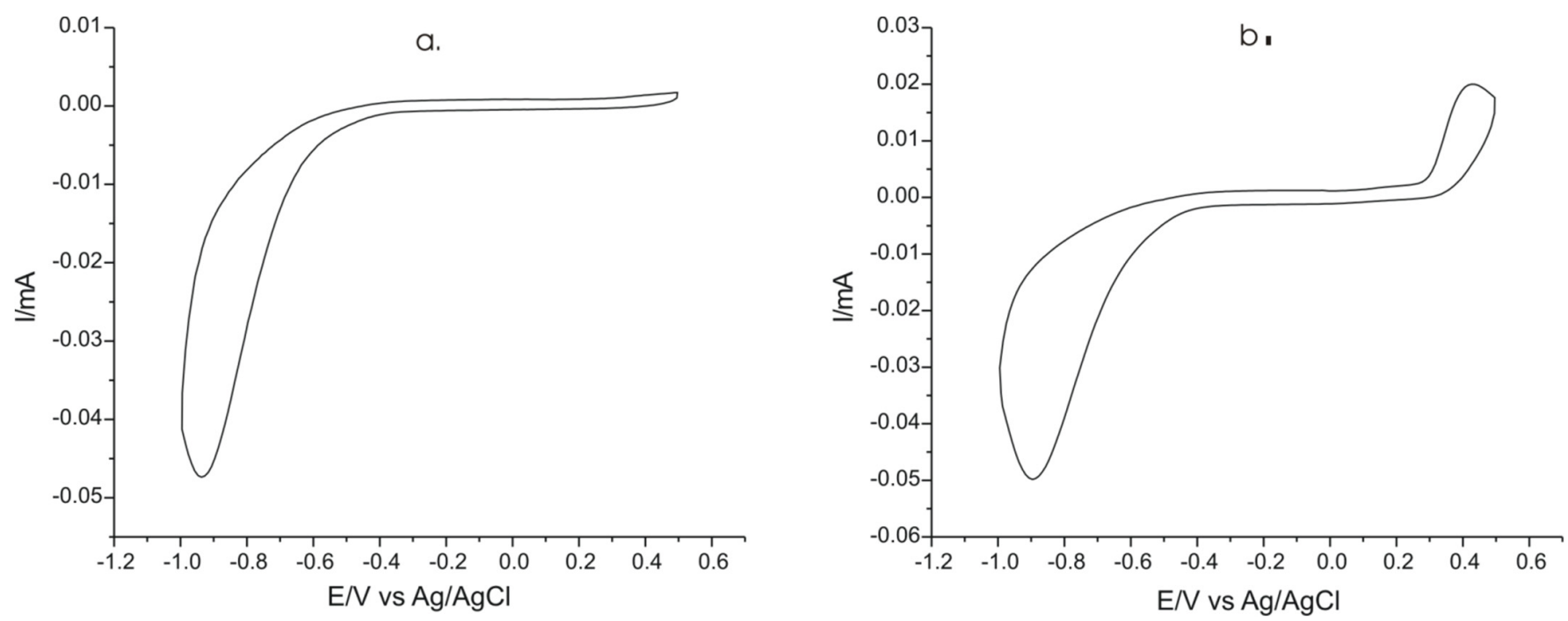

Figure 6. Electrochemical response of carbon screen-printed electrode immersed in: (a) $0.1 \mathrm{M} \mathrm{KCl}$ and (b) $0.1 \mathrm{M} \mathrm{KCl}$ and $10^{-3} \mathrm{M}$ L-Tyr solution at $0.1 \mathrm{~V} \times \mathrm{s}^{-1}$.

This step is important to be able to compare the results obtained with the unmodified sensor with modified electrodes with PPy doped with FeCN, N,P and SDS. As observed in cyclic voltammograms presented in Figure 6, the unmodified electrode immersed in both solutions have a potential window ranging from approximately -0.5 to $+0.5 \mathrm{~V}$. For the improvement of the electrochemical properties of the electrode for Tyr detection, modification with a sensitive and selective material is necessary. 
3.2.2. Stable Electrochemical Responses of Sensors in $0.1 \mathrm{M} \mathrm{KCl}$ Solutions and in Double Solution of $0.1 \mathrm{M} \mathrm{KCl}-10^{-3} \mathrm{M}$ L-Tyr Solutions

The electrochemical behavior of sensors was initially studied in a $0.1 \mathrm{M} \mathrm{KCl}$ solution, as this solution favors observing redox processes of the modifying material on the electrode surface, often being used to characterize chemically modified sensors, for example, CPs doped with different anions. The optimal potential range used was from $-1.0 \mathrm{~V}$ to $+0.5 \mathrm{~V}$, and the scan rate was $0.1 \mathrm{~V} \times \mathrm{s}^{-1}$.

After preparation, the sensors were introduced in the $0.1 \mathrm{M} \mathrm{KCl}$ solution and the cyclic voltammograms were recorded. The first three cycles were somehow different compared with the subsequent ones, and this is related to the stabilization of the PPy layer in the electrolyte solution. After six cycles, the sensor responses became stable [53].

An example of six repetitive cyclic voltammetric scans is presented in Figure 7.

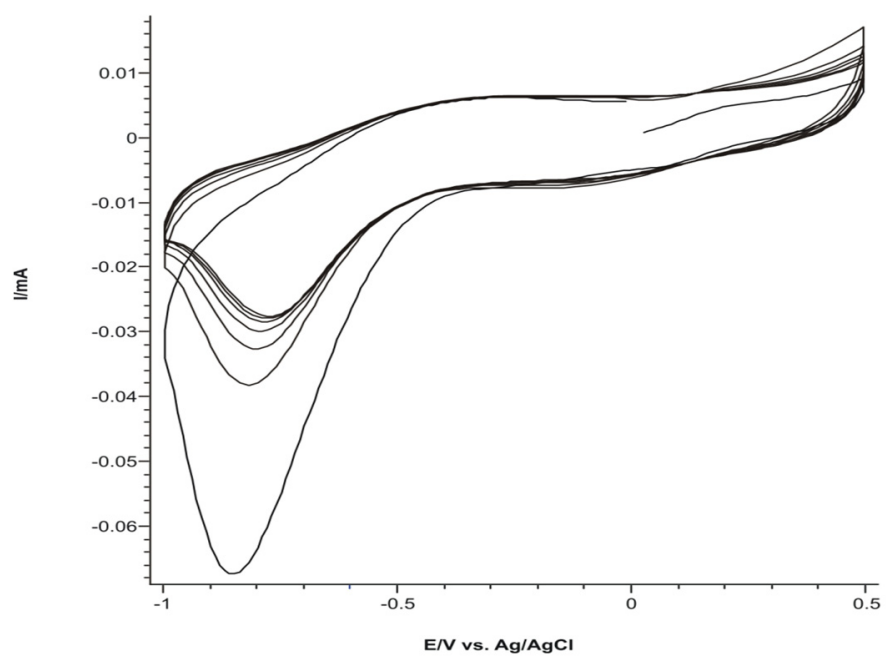

Figure 7. Six successive cyclic voltammograms of the PPy/FeCN sensor in $0.1 \mathrm{M} \mathrm{KCl}$ solution.

The stable responses of the sensors in the $0.1 \mathrm{M} \mathrm{KCl}$ solution are presented in Figure 8.
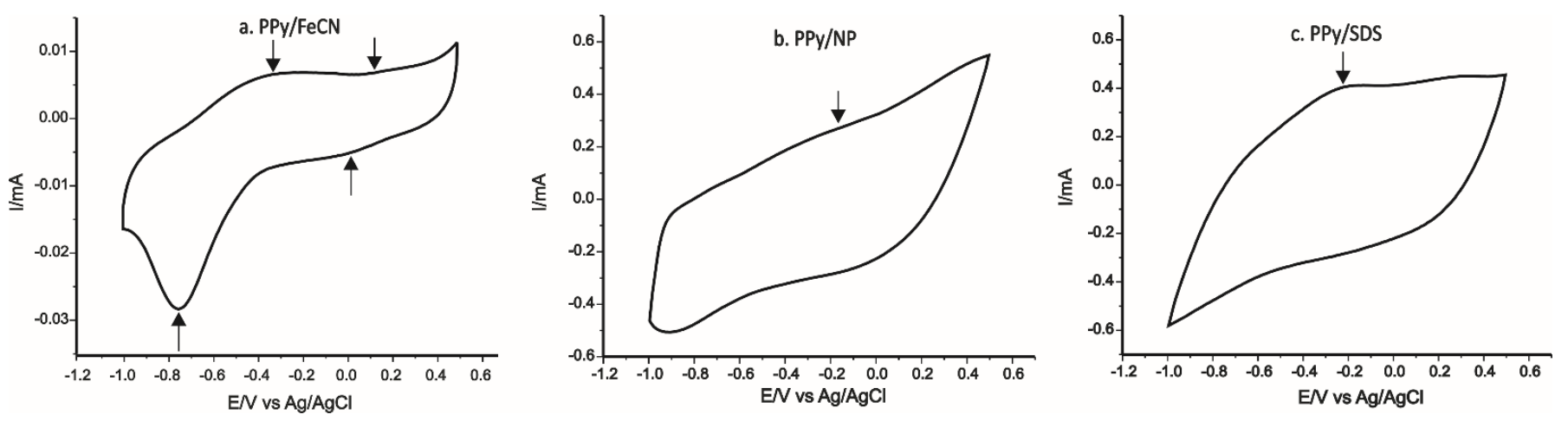

Figure 8. Stable response of polypyrrole based sensors immersed in $0.1 \mathrm{M} \mathrm{KCl}$ solution at $0.1 \mathrm{~V} \times \mathrm{s}^{-1}$ : $(\mathbf{a}) \mathrm{PPy} / \mathrm{FeCN}-\mathrm{SPCE}$; (b) PPy/NP-SPCE, and (c) PPy/SDS-SPCE.

In the case of PPy/FeCN-SPCE, we noted two anodic peaks and two cathodic peaks, which corresponded, on one hand, to the PPy redox process, whereas the II redox process corresponded to the oxidation-reduction process of potassium ferrocyanide found in the polymeric matrix. In the case of PPy/NP-SPCE and PPy/SDS-SPCE, the peaks were less defined because of the high background current and because SDS is not electroactive. Peak currents and potential achieved from CVs for each sensor are collected in Table 2. 
Table 2. The potential and intensity of peaks of PPy modified sensors and immersed in a $0.1 \mathrm{M} \mathrm{KCl}$ solution at scan rate of $0.1 \mathrm{~V} \times \mathrm{s}^{-1}$.

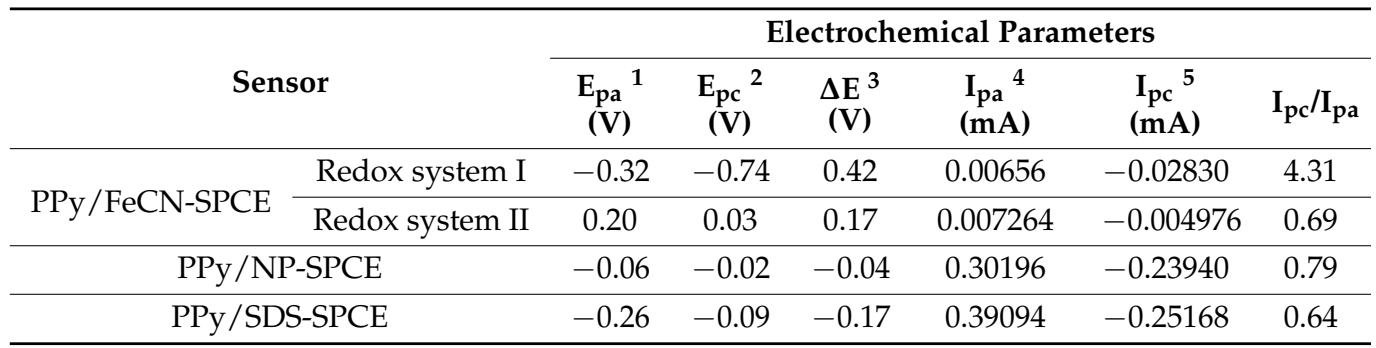

${ }^{1}$ Potential of the anodic peak; ${ }^{2}$ Potential of the cathodic peak; ${ }^{3} \Delta \mathrm{E}=\mathrm{E}_{\mathrm{pa}}-\mathrm{E}_{\mathrm{pc}}{ }^{4}$ Current of the anodic peak

${ }^{5}$ Current of the cathodic peak.

It can be noted that all peak characteristics (potential, intensity, form) achieved through the $\mathrm{KCl} 0.1 \mathrm{M}$ solution were related to the chemical nature of doping compounds included in the polymeric matrix [46]. It can be expected that a higher sensitivity can be achieved in the case of PPy/FeCN-SPCE because the peaks recorded at PPy/FeCN-SPCE in $0.1 \mathrm{M} \mathrm{KCl}$ were better defined compared with the other sensors (higher ratio between the peak and background current).

The peaks achieved have, on one hand, characteristics belonging to the PPy chain redox process and, on the other hand, they reflect the doping activity of the redox in the polymeric matrix (in the case of $\mathrm{FeCN}$ ).

The sensor PPy/FeCN-SPCE had better defined peaks and a relative reduced background current opposed to the other two sensors.

In the following step, the modified sensors were immersed into a double solution containing $0.1 \mathrm{M} \mathrm{KCl}-10^{-3} \mathrm{M} \mathrm{L}-\mathrm{Tyr}$. On detection of AA L-Tyr, the stable electrochemical responses achieved with the three PPy modified electrodes are presented in Figure 9.
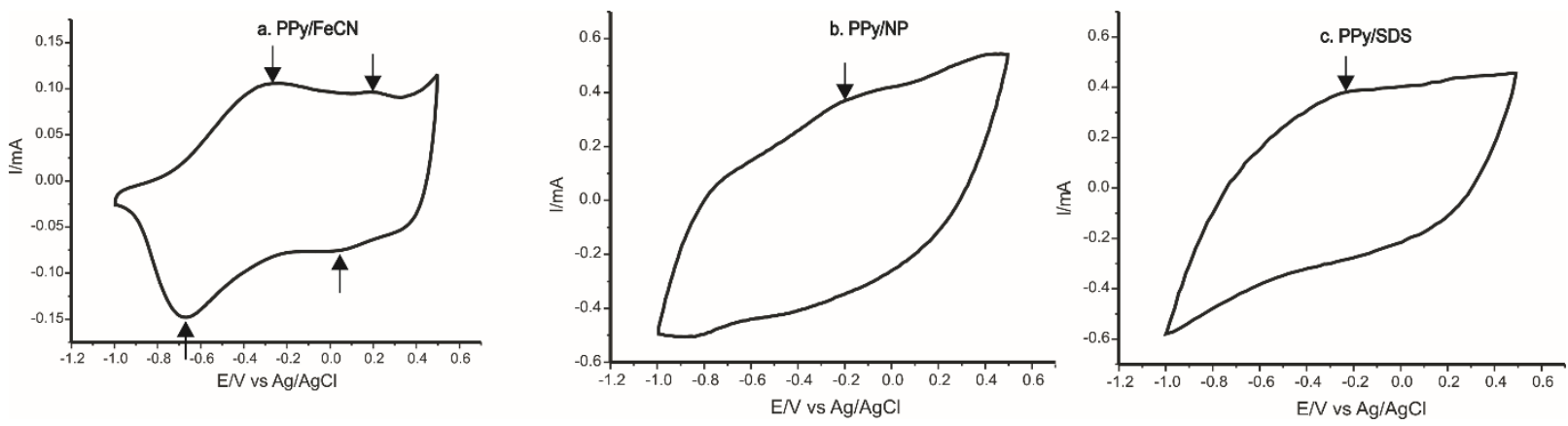

Figure 9. Stable response of polypyrrole based sensors immersed in $0.1 \mathrm{M} \mathrm{KCl}$ and $10^{-3} \mathrm{M} \mathrm{L-Tyr} \mathrm{solution} \mathrm{at} 0.1 \mathrm{~V} \times \mathrm{s}^{-1}$ : (a) PPy/FeCN-SPCE, (b) PPy/NP-SPCE, and (c) PPy/SDS-SPCE.

The intensity and potential of anodic and cathodic peaks observed in the cyclic voltammograms are presented in Table 3.

For the electrode PPy/FeCN (Figure 9a) immersed into the $0.1 \mathrm{M} \mathrm{KCl}$ and $10^{-3} \mathrm{M}$ L-Tyr solution, two anodic and cathodic peaks were identified, the first redox process appeared at $\mathrm{E}_{\mathrm{paI}}=-0.28 \mathrm{~V}$ (peak I) and corresponded to the redox properties of PPy, and the second peak at $E_{\text {paII }}=0.19 \mathrm{~V}$ corresponded to the redox reaction of the potassium ferrocyanide included in the polymeric matrix [54]. Both peak pairs, related with PPy and $\mathrm{FeCN}$, were influenced by the presence of the L-Tyr by shifting the peak potentials and increasing the peak currents, especially in the anodic scan. 
Table 3. The potential and intensity of peaks of PPy modified sensors immersed in a $0.1 \mathrm{M} \mathrm{KCl}$ and $10^{-3} \mathrm{M}$ L-Tyr solution at a scan rate of $0.1 \mathrm{~V} \times \mathrm{s}^{-1}$.

\begin{tabular}{cccccccc}
\hline \multirow{2}{*}{ Sensor } & \multicolumn{6}{c}{ Electrochemical Parameters } \\
\cline { 2 - 8 } & $\begin{array}{c}\mathbf{E}_{\mathbf{p a}} \\
\mathbf{( V )}\end{array}$ & $\begin{array}{c}\mathbf{E}_{\mathbf{p c}} \\
\mathbf{( V )}\end{array}$ & $\begin{array}{c}\Delta \mathbf{E} \\
\mathbf{( V )}\end{array}$ & $\begin{array}{c}\mathbf{I}_{\mathbf{p a}} \\
\mathbf{( m A )}\end{array}$ & $\begin{array}{c}\mathbf{I}_{\mathbf{p c}} \\
(\mathbf{m A})\end{array}$ & $\mathbf{I}_{\mathbf{p c}} / \mathbf{I}_{\mathbf{p a}}$ \\
\hline \multirow{2}{*}{$\mathrm{PPy} / \mathrm{FeCN}-S P C E$} & Redox system I & -0.28 & -0.66 & -0.38 & 0.125608 & -0.13802 & 1.09 \\
\cline { 2 - 8 } & Redox system II & 0.19 & 0.08 & 0.11 & 0.094318 & -0.085659 & 0.90 \\
\hline PPy/NP-SPCE & -0.17 & -0.12 & -0.05 & 0.376208 & -0.317410 & 0.84 \\
\hline PPy/SDS-SPCE & -0.23 & -0.13 & -0.10 & 0.384051 & -0.265026 & 0.68 \\
\hline
\end{tabular}

The response of the sensors PPy/NP (Figure 9b) and PPy/SDS (Figure 9c) immersed into a solution of $0.1 \mathrm{M} \mathrm{KCl}$ and $10^{-3} \mathrm{M} \mathrm{L}$-Tyr showed a single oxidation-reduction process due to PPy influenced by the nature of the doping agent included in the polymeric matrix.

It can be observed in Table 3 that the values $\mathrm{I}_{\mathrm{pc}} / \mathrm{I}_{\mathrm{pa}}$ calculated for the three sensors were different, with values close to the ideal one, with the best result being achieved in the case of PPy/FeCN-SPCE. This result proves that the oxidation-reduction processes at the surface of the sensor are quasi-reversible [54].

In the case of PPy/FeCN and PPy/NP, the presence of L-Tyr in the analyzed solution influenced the electrochemical response by shifting the potential of the peaks observed and increasing the peak current by comparing it with the response in the $\mathrm{KCl}$ solution, which proves that PPy/FeCN and PPy/NP sensors can be used for L-Tyr detection.

The peaks of PPy/FeCN-SPCE were lower as current in comparison to those observed for the other modified electrodes, but the ratio between the current of the peaks and the background current was better in the case of this sensor. Therefore, the PPy/FeCN-SPCE improved voltammetric responses compared with the other sensors developed in this study and the detection of L-Tyr was more accurate.

3.2.3. The Influence of the Scan Rate on the Responses of the Sensors Immersed into $0.1 \mathrm{M}$ $\mathrm{KCl}$ and $0.1 \mathrm{M} \mathrm{KCl}-10^{-3} \mathrm{M}$ L-Tyr Solutions

It is well known that the scan rate plays an important role in electrochemical measurements as it contributes to bringing out the redox processes and greatly influencing the voltammetric responses of the sensors. The voltammograms were recorded at 10 scan rates, from 0.1 to $1.0 \mathrm{~V} \times \mathrm{s}^{-1}$, in the potential range between $-1.0 \mathrm{~V}$ and $+0.5 \mathrm{~V}$, thus making possible the study of dynamic characteristics and of sensor signals.

Figure 10a presents the CVs obtained with the PPy/FeCN sensor immersed into $0.1 \mathrm{M}$ $\mathrm{KCl}$ and $10^{-3} \mathrm{M} \mathrm{L}$-Tyr solutions at scan rates between 0.1 to $1.0 \mathrm{~V} \times \mathrm{s}^{-1}$. It can be noted that there was an increase in peak intensity together with the increase in scan rate. In order to determine the limiting factor of electrochemical reactions, the linear fitting between $\mathrm{I}_{\mathrm{pa}}$ and the square root of the scan rate for PPy $/ \mathrm{FeCN}$ was carried out (Figure 10b).

The intensity of peaks is directly proportional to the square root of the scan rates, which points out that the redox processes have a diffusion process to determine the kinetics stage.

The active surfaces of the unmodified and the three modified sensors were calculated from the linear fitting equations by using the Randles-Sevcik equation:

$$
I_{p}=\left(2.69 \times 10^{5}\right) \times n^{3 / 2} \times A \times C \times D^{1 / 2} \times v^{1 / 2}
$$

where $I_{p}$ is the peak current (Amperes); $\mathrm{n}$ is the number of electrons transferred in the redox process; $\mathrm{A}$ is the electrode area $\left(\mathrm{cm}^{2}\right)$; $\mathrm{C}$ is the concentration $\left(\mathrm{mol} \times \mathrm{cm}^{-3}\right)$; $\mathrm{D}$ is the diffusion coefficient $\left(\mathrm{cm}^{2} \times \mathrm{s}^{-1}\right)$; and $\mathrm{v}$ is the scan rate $\left(\mathrm{V} \times \mathrm{s}^{-1}\right)$. The diffusion coefficient of L-Tyr is $3 \times 10^{-5} \mathrm{~cm}^{2} \times \mathrm{s}^{-1}[55]$. 

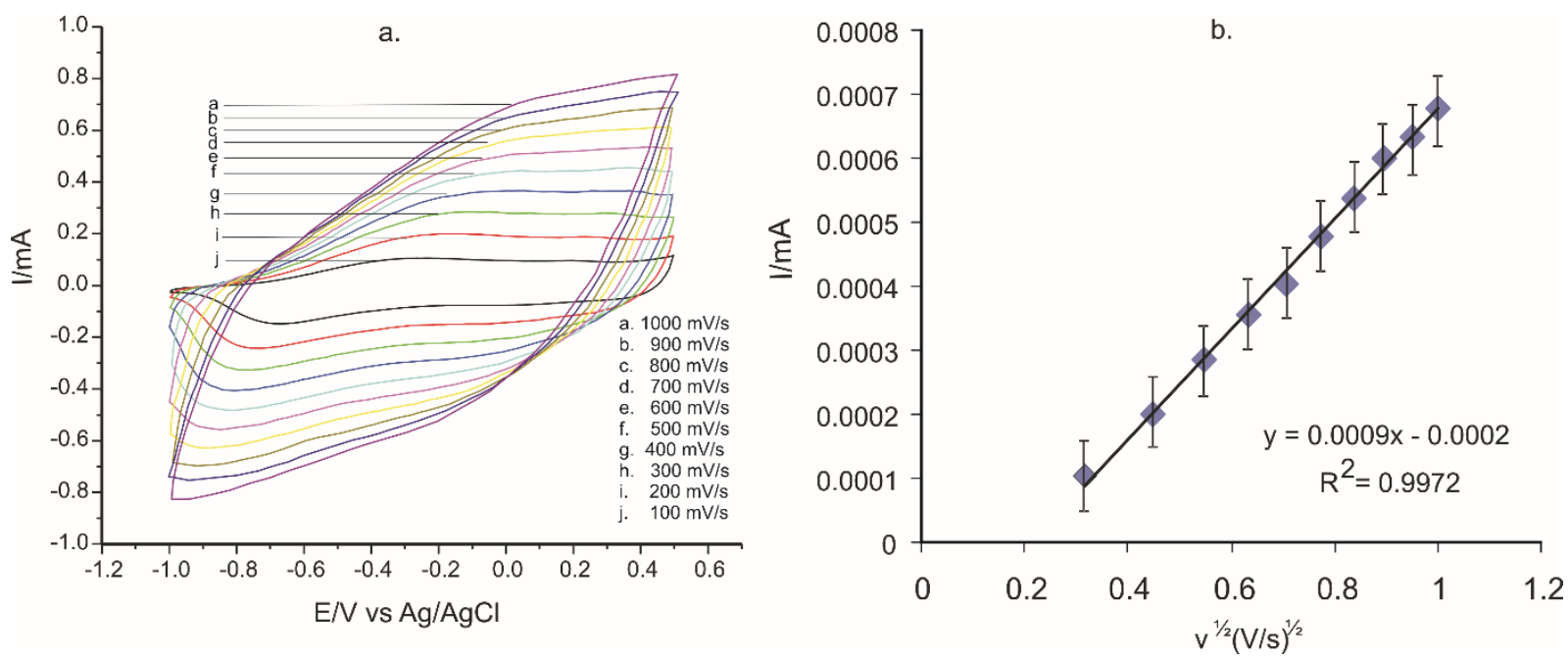

Figure 10. (a) CVs of the PPy/FeCN-SPCE sensor immersed in the $\mathrm{KCl} 0.1 \mathrm{M}$ and $10^{-3} \mathrm{M}$ L-Tyr solution, at scan rates between 0.1 and $1.0 \mathrm{~V} \times \mathrm{s}^{-1}$. (b) Linear fitting curves between $\mathrm{I}_{\mathrm{pa}}$ and square root of scan rate.

The values achieved for $\mathrm{A}$, the active area of the sensor, calculated from the slope of the equation from $\mathrm{I}_{\mathrm{pa}}$ and $\mathrm{v}^{1 / 2}$ as well as the surface roughness factor are presented in Table 4.

Table 4. Active area surface and roughness factor for the electrodes used in the analysis before and after modification.

\begin{tabular}{|c|c|c|c|c|c|}
\hline Electrode & Solution & $\begin{array}{c}\text { Slope } \\
\left(\mathrm{mA} \cdot \mathrm{s}^{1 / 2} \cdot \mathrm{V}^{-1 / 2}\right)\end{array}$ & $\mathbf{R}^{2}$ & $\begin{array}{l}\text { Active Area } \\
\left(\mathrm{cm}^{2}\right)\end{array}$ & $\begin{array}{c}\text { Roughness } \\
\text { Factor }\end{array}$ \\
\hline SPCE & & 0.00005820 & 0.9946 & 0.0803 & 0.63 \\
\hline $\mathrm{PPy} / \mathrm{FeCN}-\mathrm{SPCE}$ & \multirow{3}{*}{$\begin{array}{c}0.1 \mathrm{M} \mathrm{KCl} \\
\text { and } 10^{-3} \mathrm{M} \\
\text { L-Tyr }\end{array}$} & 0.00085700 & 0.9972 & 1.1824 & 9.41 \\
\hline PPy/NP-SPCE & & 0.00027890 & 0.972 & 0.3847 & 3.06 \\
\hline PPy/SDS-SPCE & & 0.00034100 & 0.9910 & 0.4700 & 3.74 \\
\hline
\end{tabular}

In conclusion, it can be noted that the values of the active area and roughness factor of the $\mathrm{PPy} / \mathrm{FeCN}$ sensor were the highest, thus this sensor had the highest sensitivity for L-Tyr detection.

\subsubsection{Development of Calibration Curve}

CV was used to detect L-Tyr in solutions of different concentrations. This is an important stage as the equation of the calibration curve can help calculate the limit of detection (LOD) and the limit of quantification (LOQ) of each PPy-modified sensor.

The concentration range researched was between $0.5-27 \times 10^{-6} \mathrm{M}$ for all three electrodes developed in this study. One can note that for all three sensors, there was a linear increase in the anodic intensity peak once the Tyr concentration increased. The sensitivity of the $\mathrm{PPy} / \mathrm{FeCN}-\mathrm{SPCE}$, PPy/NP-SPCE, PPy/SDS-SPCE, and unmodified SPCE for determination of L-Tyr were: $1.463 \mathrm{~A} / \mathrm{M}, 0.2789 \mathrm{~A} / \mathrm{M}, 0.3412 \mathrm{~A} / \mathrm{M}$, and $0.1543 \mathrm{~A} / \mathrm{M}$, respectively.

As an example, Figure 11 presents the results obtained with PPy/FeCN-SPCE. Figure 11a shows the electrochemical responses of the $\mathrm{PPy} / \mathrm{FeCN}$ sensor at different concentrations of L-Tyr in the range $0.5-27 \times 10^{-6} \mathrm{M}$. A zoom of the anodic peaks zone is presented in Figure 11b. In Figure 11c is observed the increment of the anodic peak current I of the sensor PPy $/ \mathrm{FeCN}$ when the concentration of the L-Tyr solution increased. The dependence is linear when L-Tyr concentrations are lower, followed by a plateau where current increment is not linear, which means that the sensor has reached a saturation level (Figure 11c). 
In the concentration range $0.5-5 \times 10^{-6} \mathrm{M}$, the current increased directly with the L-Tyr concentration, the dependence having a determination coefficient of 0.99 (Figure 11d).
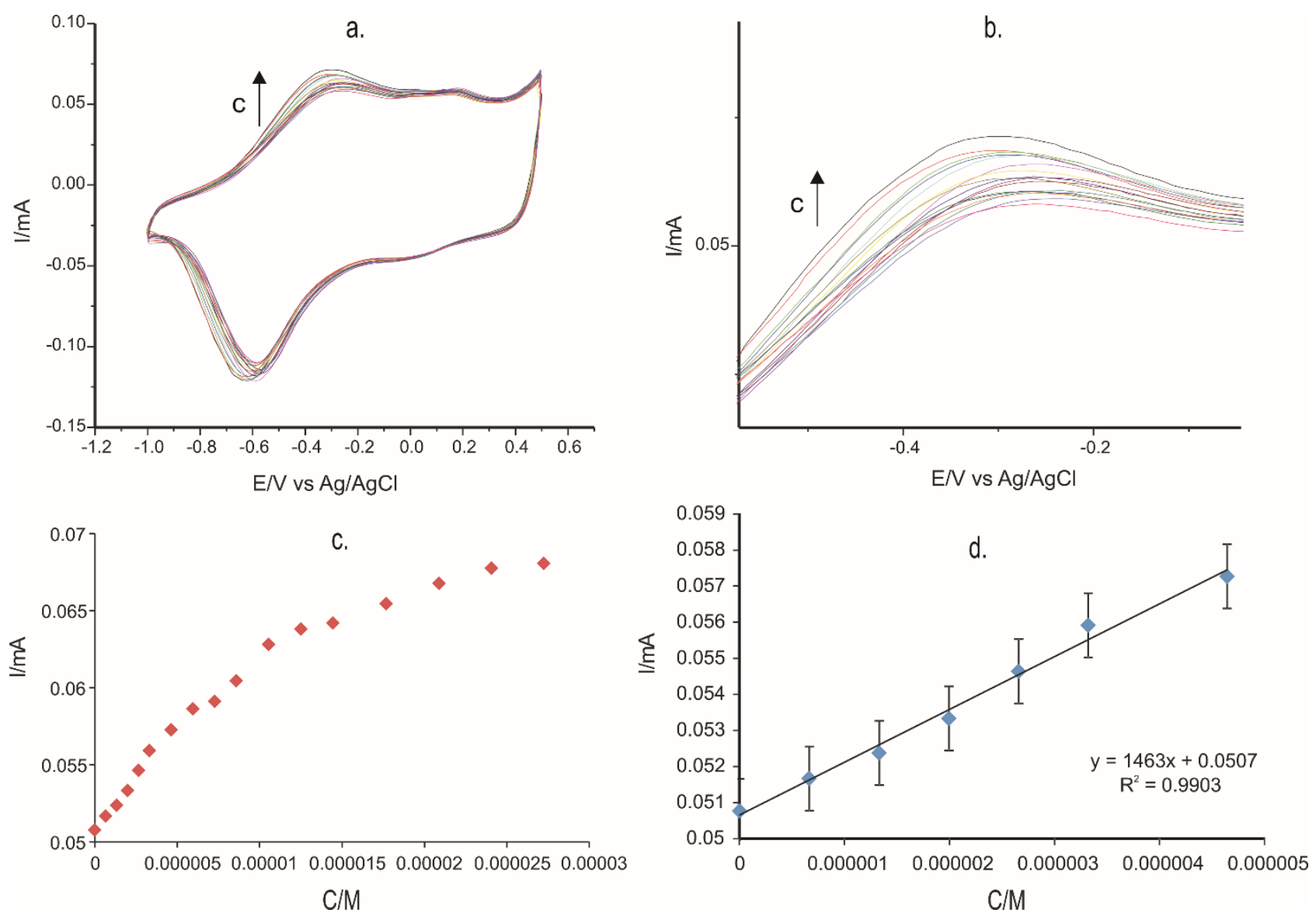

Figure 11. (a) Cyclic voltammograms obtained for different concentrations of L-Tyr in the range $0.5-27 \times 10^{-6} \mathrm{M}$. (b) The zoom on the anodic peak for which the calibration curve was developed. (c) The anodic peak current I variation with Tyr concentration. (d) Calibration curve in the range $0.5-5 \times 10^{-6} \mathrm{M}$.

The voltammetric determinations were achieved with all three sensors, and Table 5 shows the LOD and LOQ obtained through Tyr detection.

Table 5. Data achieved from the calibrations curves for PPy/FeCN, PPy/NP, and PPy/SDS sensors at Tyr detection.

\begin{tabular}{ccc}
\hline Sensor & LOD $^{\mathbf{1}} \mathbf{( M )}$ & LOQ $^{\mathbf{2}} \mathbf{( M )}$ \\
\hline PPy/FeCN-SPCE & $8.20 \times 10^{-8}$ & $2.73 \times 10^{-7}$ \\
\hline PPy/NP-SPCE & $4.30 \times 10^{-7}$ & $1.43 \times 10^{-6}$ \\
\hline PPy/SDS-SPCE & $3.51 \times 10^{-7}$ & $1.17 \times 10^{-6}$ \\
\hline
\end{tabular}

${ }^{1}$ Limit of detection; ${ }^{2}$ Limit of quantification.

The lowest LOD and LOQ values were achieved for the PPy/FeCN-SPCE sensor. The results obtained with the sensors developed in this study are comparable with those obtained with other sensors used for the electrochemical detection of L-Tyr reported in the literature, as presented in Table 6, where some sensors even had lower values of LODs [56-65]. However, the sensors developed in this study have a series of advantages. 
Table 6. Performance characteristics of several electrochemical sensors in the detection of tyrosine.

\begin{tabular}{|c|c|c|c|c|c|c|}
\hline No. & Sensitive Material & $\begin{array}{l}\text { Electroanalytical } \\
\text { Technique }\end{array}$ & Linearity Range (M) & LOD (M) & $\begin{array}{l}\text { Real Samples } \\
\text { Analyzed }\end{array}$ & Reference \\
\hline 1 & $\begin{array}{c}\text { In situ copper oxide modified } \\
\text { MIPPy coated GCE }\end{array}$ & $\mathrm{DPV}^{1}$ & $1.0 \times 10^{-8}-8.0 \times 10^{-6}$ & $4.0 \times 10^{-9}$ & human serum & {$[56]$} \\
\hline 2 & $\begin{array}{c}\text { MWCNTs-doped } \\
\text { Poly(glycine)/Poly(acrylic } \\
\text { acid)/SPE }\end{array}$ & $\mathrm{LSV}^{2}$ & $4.0 \times 10^{-7}-1.5 \times 10^{-4}$ & $1.3 \times 10^{-7}$ & human serum & [57] \\
\hline 3 & $\begin{array}{c}\text { AuNPs/poly } \\
\text { (trisamine)/GCE }\end{array}$ & DPV, EIS ${ }^{3}$ & $3.9 \times 10^{-6}-6.18 \times 10^{-5}$ & $9.0 \times 10^{-7}$ & $\begin{array}{l}\text { human blood } \\
\text { serum }\end{array}$ & [58] \\
\hline 4 & $\begin{array}{l}\text { Poly threonine modified } \\
\text { graphite-carbon nanotube } \\
\text { paste electrode }\end{array}$ & $\mathrm{CV}^{4}$ & $2.0 \times 10^{-6}-2.5 \times 10^{-5}$ & $2.9 \times 10^{-7}$ & black tea & [59] \\
\hline 5 & Poly-L-serine/GCE & Amperometry & $3.0 \times 10^{-7}-1.0 \times 10^{-4}$ & $1.0 \times 10^{-7}$ & $\begin{array}{l}\text { commercial } \\
\text { amino acid oral } \\
\text { solution }\end{array}$ & {$[60]$} \\
\hline 6 & MIP-polypyrrole/AuE & $\mathrm{SWV}^{5}$ & $5.0 \times 10^{-9}-2.5 \times 10^{-8}$ & $2.5 \times 10^{-9}$ & human plasma & {$[61]$} \\
\hline 7 & $\begin{array}{l}\text { GC/CNT/PEDOT/NF/Crown } \\
\text { (glassy carbon/multi-walled } \\
\text { carbon nanotubes/poly } \\
\text { (3-4-ethylene } \\
\text { dioxythiophene/Nafion/Crown) }\end{array}$ & DPV & $6.0 \times 10^{-8}-2.0 \times 10^{-5}$ & $4.29 \times 10^{-10}$ & blood serum & [62] \\
\hline 8 & $\begin{array}{l}\text { over-oxidized polypyrrole } \\
\text { film on indium tin oxide }\end{array}$ & $\mathrm{CV}$ & $1.0 \times 10^{-13}-1.0 \times 10^{-6}$ & $1.73 \times 10^{-12}$ & - & {$[63]$} \\
\hline 9 & $\begin{array}{c}\text { MIP/pTH/Au@ZIF-67 } \\
\text { (molecularly } \\
\text { imprinted polyani- } \\
\text { line/polythionine/gold } \\
\text { nanoparticles@zeolitic } \\
\text { imidazolate framework-67 } \\
\text { composite () }\end{array}$ & DPV & $1.0 \times 10^{-8}-4.0 \times 10^{-6}$ & $7.9 \times 10^{-10}$ & human serum & {$[64]$} \\
\hline 10 & $\begin{array}{l}\text { EB-Ppy-BSA/GCE (Electron } \\
\text { beam irradiated polypyrrole } \\
\text { nanospheres embedded over } \\
\text { bovine serum albumin/) }\end{array}$ & SWV & $1.0 \times 10^{-7}-8.0 \times 10^{-4}$ & $8.8 \times 10^{-9}$ & $\begin{array}{l}\text { black tea and } \\
\text { chicken extract }\end{array}$ & {$[65]$} \\
\hline 11 & $\begin{array}{c}\mathrm{BuCh} / \mathrm{GCE} \\
\begin{array}{c}\text { (butyrylcholine/glassy } \\
\text { carbon electrode) }\end{array}\end{array}$ & DPV & $4.0 \times 10^{-6}-1.0 \times 10^{-4}$ & $4.0 \times 10^{-7}$ & $\begin{array}{l}\text { mixture of } \\
\text { amino acids }\end{array}$ & [32] \\
\hline 12 & $\begin{array}{l}\text { cAuNPs/2-AETGO/GCE } \\
\text { (cubic gold nanoparticles/2- } \\
\text { aminoethanethiol } \\
\text { functionalized graphene } \\
\text { oxide/glassy carbon } \\
\text { electrode) }\end{array}$ & DPV & $1.0 \times 10^{-9}-2.0 \times 10^{-8}$ & $1.5 \times 10^{-10}$ & milk & [33] \\
\hline 13 & $\begin{array}{c}\text { GC/RGO/ILC/CNT/Fe-Zn } \\
\text { (glassy carbon } \\
\text { electrode/graphene } \\
\text { oxide/ionic liquid } \\
\text { crystal/multi-walled carbon } \\
\text { nanotubes/Fe-Zn nanoalloy) }\end{array}$ & DPV & $2.0 \times 10^{-8}-5.0 \times 10^{-5}$ & $5.1 \times 10^{-9}$ & biological fluids & [19] \\
\hline
\end{tabular}

${ }^{1}$ DPV—Differential pulse voltammetry; ${ }^{2}$ LSV—Linear sweep voltammetry, ${ }^{3}$ EIS-Electrochemical impedance spectroscopy, ${ }^{4} \mathrm{CV}-\mathrm{Cyclic}$ voltammetry, ${ }^{5}$ SWV-Square wave voltammetry.

The advantages of polypyrrole based sensors are the simplicity of preparation in a single stage, good reproducibility of the sensors' preparation, good stability, appropriate sensitivity and selectivity for the detection of tyrosine, low cost, and require low quantities of samples. Furthermore, in the case of PPy/FeCN-SPCE, the presence of an electroactive doping agent in the polypyrrole matrix increases the sensitivity by mediating the electron transfer process. 


\subsubsection{Precision, Reproducibility, and Stability of the Modified Sensor}

Precision studies were performed on L-Tyr solutions of $4 \times 10^{-6} \mathrm{M}$ for inter-day and intra-day precision with the PPy/FeCN-SPCE sensor. Intra-day accuracy was achieved at three different times of the day ( $3 \mathrm{~h}$ interval), and inter-day accuracy was evaluated for three different days, and the relative standard deviation (RDS\%) values of the voltammetric signals are reported in Table 7.

To evaluate the reproducibility of the sensor modified with PPy and doped with FeCN, measurements were performed for six replicates, using $4 \times 10^{-6} \mathrm{M} \mathrm{L}$-Tyr solution. After each experiment, the sensor was taken from the solution, rinsed with ultrapure water, dried in a desiccator, and re-immersed in the solution. The relative standard deviation (RDS) of the six cyclic voltammograms replicates was 3.3\%.

Regarding the electrode stability, this was determined in the same L-Tyr solution during three weeks. After three weeks, it was found that the electrode kept $91 \%$ of the initial signal response. The sensors were stored in the refrigerator at a temperature of $4{ }^{\circ} \mathrm{C}$ in a closed dry box when they were not used.

Table 7. Precision, reproducibility, and stability of the PPy/FeCN-SPCE sensor.

\begin{tabular}{|c|c|c|c|c|}
\hline \multicolumn{2}{|c|}{$\begin{array}{c}\text { Precision } \\
\text { (RSD\%) }\end{array}$} & \multirow[t]{2}{*}{$\begin{array}{l}\text { Reproducibility } \\
\text { (RSD\%) }\end{array}$} & \multicolumn{2}{|r|}{ Stability } \\
\hline Intra-day & Inter-day & & Time (days) & Relative Current response (\%) \\
\hline \multirow{3}{*}{4.4} & \multirow{3}{*}{5.7} & \multirow{3}{*}{3.3} & 5 & 97 \\
\hline & & & 16 & 94 \\
\hline & & & 21 & 91 \\
\hline
\end{tabular}

\subsubsection{Interference Study}

To evaluate sensor selectivity for L-Tyr detection in complex samples, the influence of several amino acids (tryptophan, cysteine, and phenylalanine) was studied as these amino acids could interfere in electroanalysis. The concentration of the L-Tyr was $4 \times 10^{-6} \mathrm{M}$ and the detection technique was cyclic voltammetry. The tolerance limit was calculated as being the maximum concentration of the interfering amino acids, which causes a relative error of $\pm 5 \%$ for the tyrosine quantification. The results obtained are shown in Table 8 .

Table 8. The interference of several amino acids on the quantification of $4 \times 10^{-6} \mathrm{M} \mathrm{L-Tyr}$.

\begin{tabular}{ccccc}
\hline Amino Acid & c/M & [Tyr]/M & RE (\%) & Recovery (\%) \\
\hline L-Tryptophan & 0.001 & $3.812 \times 10^{-6}$ & -4.7 & 95.3 \\
\hline L-Cysteine & 0.001 & $3.815 \times 10^{-6}$ & -4.625 & 95.375 \\
\hline L-Phenylalanine & 0.001 & $4.813 \times 10^{-6}$ & 4.575 & 104.575 \\
\hline $\begin{array}{l}\text { c-Concentration of interfering AAs; } \\
\text { RE- }[\text { Tyr] - Concentrative error in quantification of Tyr. }\end{array}$
\end{tabular}

The quantification of L-Tyr is influenced by the presence of other AAs in the analyzed solution, the relative errors being close to $\pm 5 \%$ and recoveries in the range $95.3-104.575 \%$. Based on these results, it could be concluded that PPy / FeCN-SPCE is selective for L-Tyr quantification in samples containing up to $0.001 \mathrm{M}$ of tryptophan, cysteine, and phenylalanine.

\subsubsection{Validation of Modified Sensors on Real Samples}

Three pharmaceutical products from three different manufacturers with different Tyr concentrations were selected and analyzed in order to validate the sensors made in this research through AA L-Tyr quantification. The samples were obtained from a local pharmacy. The three pharmaceutical products used were L-tyrosine (Solaray) (L-Tyr 
$500 \mathrm{mg}$ ), Tiroidin (Parapharm) (L-Tyr $90 \mathrm{mg}$ ), and Cebrium (Ever Neuro Pharma) (L-Tyr $4.012 \mathrm{mg}$ ) and they were analyzed by CV.

The amounts of AAs in the pharmaceutical product Cebrium are $4.012 \mathrm{mg} \mathrm{L-Tyr}$, $1.02 \mathrm{mg}$ tryptophan, and $4.012 \mathrm{mg}$ phenylalanine. Therefore, the concentrations of each AA in the solution analyzed were at the similar level. Taking into account the results obtained in the interference studies, the concentration of the interfering AAs were under the concentration threshold values, which can cause a relative error of $\pm 5 \%$ for the tyrosine quantification.

PPy/FeCN-SPCE was used to detect and quantify L-Tyr in the pharmaceutical products as it had the best analytical performances among the three sensors developed in this research study.

The cyclic voltammograms recorded with PPy/FeCN-SPCE for the two pharmaceutical products containing $10^{-3} \mathrm{M}$ L-Tyr in the analyzed solution are shown in Figure 12.
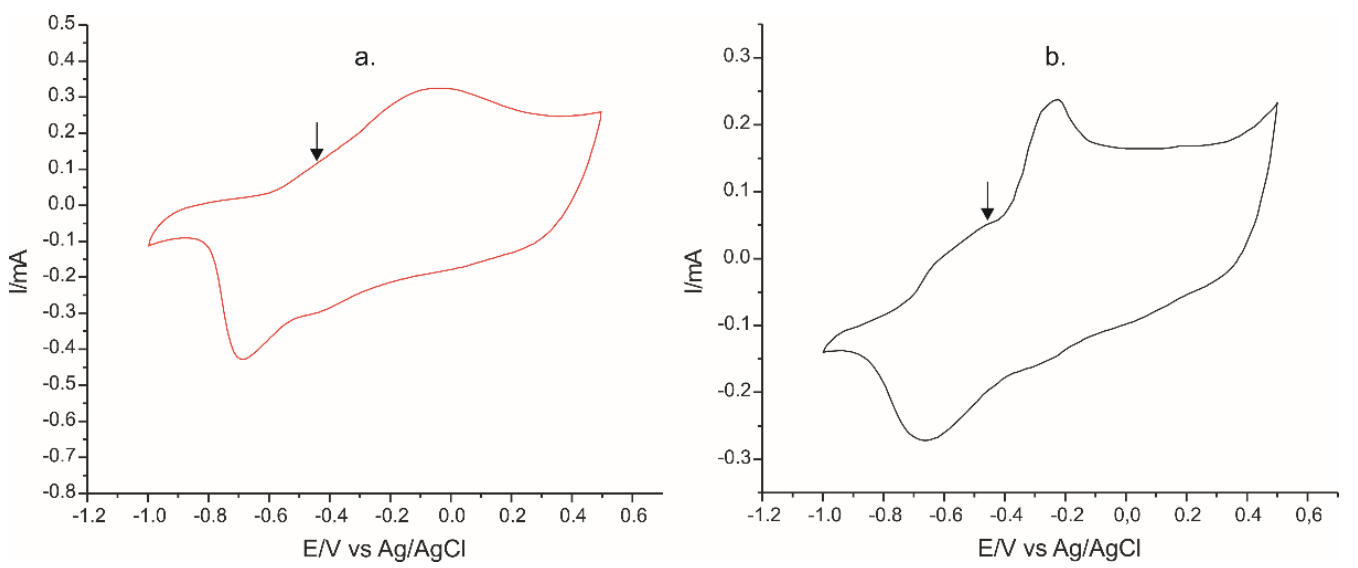

Figure 12. Voltammetric responses of the PPy/FeCN sensor in a solution of: (a) L-Tyrosine (SOLARAY); (b) Cebrium (EVER NEURO PHARMA). Estimated concentration of L-Tyr in the solutions was $10^{-3} \mathrm{M}$, in agreement with the quantity declared by producers in the pharmaceutical products.

The CVs of the sensor immersed in the pharmaceutical sample solutions were somehow different when compared with the $\mathrm{CV}$ in the model solutions. The $\mathrm{CV}$ in the solution of Cebrium was more complex and different when comparing the CVs in Tyr solution or Solaray solution. This is related with the presence of different amino acids in this sample.

However, the influence of interfering compounds was low when the concentrations of L-Tyr and interfering species were low. For example, in Figure 13a,b, the responses of the $\mathrm{PPy} / \mathrm{FeCN}-\mathrm{SPCE}$ in $0.1 \mathrm{M} \mathrm{KCl}$ solution (background), in $2 \times 10^{-6} \mathrm{M}$ solution of standard spike (solution obtained from pure L-Tyr), and in pharmaceutical product Cebrium spike solution corresponding to $2 \times 10^{-6} \mathrm{M} \mathrm{L}$-Tyr added (estimated L-Tyr total concentration $4 \times 10^{-6} \mathrm{M}$ ) are presented. The area where the Tyr signal appears is magnified (Figure 13b).

For the quantitative analysis of pharmaceutical products, the standard addition method was used. The spike and recovery experiments were carried out by measuring CV responses for pharmaceutical samples in which a known concentration of L-Tyr was added. Three additions of L-Tyr standard solution were carried out in the solution of each pharmaceutical product. The results obtained are presented in Table 9. The analyses were carried out in triplicate for each pharmaceutical product and with three different sensors. The coefficients of variation of the calculated recoveries are included in Table 9. 

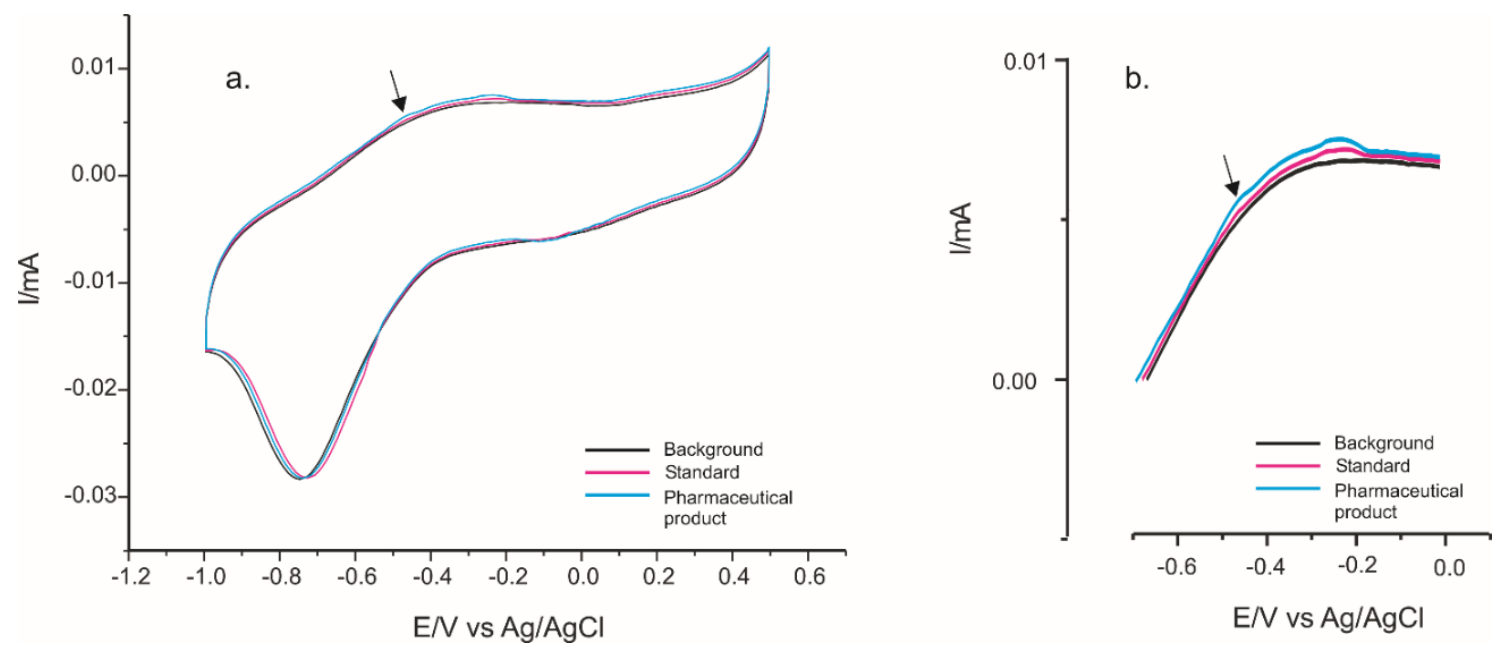

Figure 13. (a) Cyclic voltammograms of the PPy/FeCN sensor in solution $\mathrm{KCl}$ solution (background), L-Tyr solution (standard spike, $2 \times 10^{-6} \mathrm{M}$ ), Cebrium spike solution (estimated total concentration $4 \times 10^{-6} \mathrm{M}$ of L-Tyr). (b) Zoom of the cyclic voltammograms in the zone of L-Tyr detection.

Table 9. The quantitative results obtained for L-Tyr detection in pharmaceuticals by the standard addition method.

\begin{tabular}{|c|c|c|c|c|}
\hline Pharmaceutical Product & [Tyr]/M Added & I vs. [Tyr] Equation & [Tyr]/M Found & Recovery (\%) \\
\hline \multirow{3}{*}{$\begin{array}{c}\text { Cebrium EVER NEURO PHARMA } \\
\text { [Tyr] } 3 \times 10^{-6} \mathrm{M}\end{array}$} & $2 \times 10^{-6}$ & \multirow{3}{*}{$\begin{array}{c}\mathrm{I}=1.0814 c+5 \times 10^{-5} \\
\mathrm{R}^{2}=0.9982\end{array}$} & $5.17847 \times 10^{-6}$ & $103.57 \pm 1.50$ \\
\hline & $3 \times 10^{-6}$ & & $6.14944 \times 10^{-6}$ & $102.49 \pm 1.47$ \\
\hline & $4 \times 10^{-6}$ & & $7.02793 \times 10^{-6}$ & $100.40 \pm 1.08$ \\
\hline \multirow{3}{*}{$\begin{array}{l}\text { L-Tyrosine } 500 \text { SOLARAY } \\
\text { [Tyr] } 3 \times 10^{-6} \mathrm{M}\end{array}$} & $2 \times 10^{-6}$ & \multirow{3}{*}{$\begin{array}{c}\mathrm{I}=1.0869 c+5 \times 10^{-5} \\
\mathrm{R}^{2}=0.9975\end{array}$} & $5.19827 \times 10^{-6}$ & $103.97 \pm 1.55$ \\
\hline & $3 \times 10^{-6}$ & & $6.15512 \times 10^{-6}$ & $102.59 \pm 1.52$ \\
\hline & $4 \times 10^{-6}$ & & $7.01997 \times 10^{-6}$ & $100.29 \pm 1.02$ \\
\hline \multirow{3}{*}{$\begin{array}{l}\text { Tiroidin PARAPHARM } \\
\text { [Tyr] } 3 \times 10^{-6} \mathrm{M}\end{array}$} & $2 \times 10^{-6}$ & \multirow{3}{*}{$\begin{array}{c}\mathrm{I}=1.0937 c+5 \times 10^{-5} \\
\mathrm{R}^{2}=0.9991\end{array}$} & $5.10195 \times 10^{-6}$ & $102.04 \pm 1.53$ \\
\hline & $3 \times 10^{-6}$ & & $6.0437 \times 10^{-6}$ & $100.73 \pm 1.12$ \\
\hline & $4 \times 10^{-6}$ & & $6.99461 \times 10^{-6}$ & $99.92 \pm 1.09$ \\
\hline
\end{tabular}

The coefficient of variation was calculated from three measurements with three $\mathrm{PPy} / \mathrm{FeCN}-\mathrm{SPCE}$ sensors prepared in the same conditions.

The recoveries for L-Tyr for the PPy/FeCN sensor obtained by using the standard addition method were in the range $99.92-103.97 \%$, which clearly demonstrates the applicability in practice of the developed sensor.

These results demonstrate the efficiency of the electrochemical method based on sensors upon L-Tyr quantification.

\section{Conclusions}

The PPy films with the ion doping FeCN, NP, and SDS were successfully synthesized through the CA method and deposited on screen-printed carbon electrodes. The sensors were used in order to detect L-Tyr in standard solutions and pharmaceutical products, and it showed that PPy/FeCN-SPCE had the best electroanalytical performances. Good analytical performances were achieved by using $\mathrm{CV}$, which indicates that this sensor can be used in screening analysis. The method based on using PPy/FeCN-SPCE for the quantification of L-Tyr was verified by the standard addition method, which obtained good recovery values. The electroanalytical method has some important advantages when it comes to laboratory practice such as its precision, reliability, simplicity, and low cost. The sensor exhibits fast response, good sensitivity, and stability for the voltamperometric detection of 
L-tyrosine, also being useful for the selective determination of complex samples containing different AAs. The voltamperometric method can be used when performing quality control on pharmaceutical products and phytoproducts as well as other samples of interest.

Author Contributions: Conceptualization, C.A. and A.D.; Methodology, C.A.; Validation, C.A. and A.D.; Formal analysis, A.D.; Investigation, C.A. and A.D.; Data curation, C.A. and A.D.; Writingoriginal draft preparation, A.D.; Writing-review and editing, C.A.; Supervision, C.A. All authors have read and agreed to the published version of the manuscript.

Funding: The contribution of the author Ancuta Dinu was supported by the project ANTREPRENORDOC, in the framework of Human Resources Development Operational Program 2014-2020, financed from the European Social Fund under the contract number 36355/23.05.2019 HRD OP/380/6/13SMIS Code: 123847.

Institutional Review Board Statement: Not applicable.

Informed Consent Statement: Not applicable.

Data Availability Statement: The authors confirm that the data supporting the findings of this study are available within the article.

Conflicts of Interest: The authors declare no conflict of interest. The funders had no role in the design of the study; in the collection, analyses, or interpretation of data; in the writing of the manuscript, or in the decision to publish the results.

\section{References}

1. Dubey, S.; Biswas, P.; Ghosh, R.; Chatterjee, S.; Dubey, M.J.; Chatterjee, S.; Lahirir, D.; Lavie, C.J. Psychosocial impact of COVID-19. Diabetes Metab. Syndr. Clin. Res. Rev. 2020, 14, 779-788. [CrossRef]

2. Fotuhi, M.; Mian, A.; Meysami, S.; Raji, C.A. Neurobiology of COVID-19. J. Alzheimers Dis. 2020, 76, 3-19. [CrossRef] [PubMed]

3. Liguori, C.; Pierantozzi, M.; Spanetta, M.; Sarmati, L.; Cesta, N.; Iannetta, M.; Ora, J.; Mina, G.G.; Puxeddu, E.; Balbi, O.; et al. Depressive and anxiety symptoms in patients with SARS-CoV2 infection. J. Affect. Disord. 2021, 278, 339-340. [CrossRef] [PubMed]

4. Salamanca, N.; Giráldez, I.; Morales, E.; de la Rosa, I.; Herrera, M. Phenylalanine and Tyrosine as Feed Additives for Reducing Stress and Enhancing Welfare in Gilthead Seabream and Meagre. Animals 2020, 11, 45. [CrossRef] [PubMed]

5. Brock, W.H. Justus von Liebig: The Chemical Gatekeeper; Cambridge University Press: Cambridge, UK, 2002 ; pp. 37-45.

6. Zheng, F.; Zhou, J.; Wang, C.; Hu, W.; Krischek, B. There may be no significant increase of cerebrospinal fluid tyrosine levels in patients with Parkinson's disease. Eur. J. Neurol. 2021, 28, e15-e16. [CrossRef] [PubMed]

7. Hughes, J.H.; Wilson, P.J.M.; Sutherland, H.; Judd, S.; Hughes, A.T.; Milan, A.M.; Jarvis, J.C.; Bou-Gharios, G.; Ranganath, L.; Gallagher, J.A. Dietary restriction of tyrosine and phenylalanine lowers tyrosinemia associated with nitisinone therapy of alkaptonuria. J. Inherit. Metab. Dis. 2020, 43, 259-268. [CrossRef] [PubMed]

8. Hakim, M.R.; Krausz, M.J.; Spiegel, M.R. Degenerative osteoarthritis with multiple joint arthroplasties due to alkaptonuria: A rare inborn error of tyrosine metabolism. Isr. Med. Assoc. J. 2018, 20, $260-261$.

9. Park, H.J.; Nam, B.E.; Moon, S.Y.; Kim, S.-G.; Joo, Y.; Kim, J.G. Reduced host plant growth and increased tyrosine-derived secondary metabolites under climate change and negative consequences on its specialist herbivore. Sci. Total Environ. 2021, 759, 143507. [CrossRef]

10. Coley, P.D.; Endara, M.J.; Ghabash, G.; Kidner, C.A.; Nicholls, J.A.; Pennington, R.T.; Mills, A.G.; Soule, A.J.; Lemes, M.R.; Stone, G.N.; et al. Macroevolutionary patterns in overexpression of tyrosine: An anti-herbivore defence in a speciose tropical tree genus Inga (Fabaceae). J. Ecol. 2019, 107, 1620-1632. [CrossRef]

11. Kühn, S.; Duzel, S.; Colzato, L.; Norman, K.; Gallinat, J.; Brandmaier, A.M.; Lindenberger, U.; Widaman, K.F. Food for thought: Association between dietary tyrosine and cognitive performance in younger and older adults. Psychol. Res. 2019, 83, 1097-1106. [CrossRef]

12. Varmira, K.; Mohammadi, G.; Mahmoudi, M.; Khodarahmi, R.; Rashidi, K.; Hedayati, M.; Goicoechea, H.C.; Jalalvand, A.R. Fabrication of a novel enzymatic electrochemical biosensor for determination of tyrosine in some food samples. Talanta 2018, 183, 1-10. [CrossRef]

13. Dinu, A.; Apetrei, C. A Review on Electrochemical Sensors and Biosensors Used in Phenylalanine Electroanalysis. Sensors 2020, 20, 2496. [CrossRef] [PubMed]

14. Dinu, A.; Apetrei, C. Voltammetric Determination of Phenylalanine Using Chemically Modified Screen-Printed Based Sensors. Chemosensors 2020, 8, 113. [CrossRef]

15. Daly, A.; Evans, S.; Chahal, S.; Santra, S.; Pinto, A.; Gingell, C.; Rocha, J.; van Spronsen, F.; Jackson, R.; MacDonald, A. The Effect of Glycomacropeptide versus Amino Acids on Phenylalanine and Tyrosine Variability over 24 Hours in Children with PKU: A Randomized Controlled Trial. Nutrients 2019, 11, 520. [CrossRef] [PubMed] 
16. Litwack, G. Proteins. In Human Biochemistry; Academic Press: Cambridge, MA, USA, 2017; Chapter 4; pp. 65-80.

17. Hatada, T.; Sakanoue, Y.; Kusunoki, M.; Kobayashi, A.; Utsunomiya, J. Variable Activity of Protein Tyrosine Kinase in Apparently Normal Thyroid Glands. Cancer Investig. 1994, 12, 26-32. [CrossRef] [PubMed]

18. Ishihara, S.; Onoda, N.; Noda, S.; Tauchi, Y.; Morisaki, T.; Asano, Y.; Kashiwagi, S.; Takashima, T.; Ohira, M. Treatment of anaplastic thyroid cancer with tyrosine kinase inhibitors targeted on the tumor vasculature: Initial experience in clinical practice. Endocr. J. 2020, EJ20-0287. [CrossRef] [PubMed]

19. Atta, N.F.; Galal, A.; Ahmed, Y.M. An Innovative Design of an Efficient Layered Electrochemical Sensor for Determination of Tyrosine and Tryptophan in the Presence of Interfering Compounds in Biological Fluids. J. Electrochem. Soc. 2020, $167,027505$. [CrossRef]

20. Phelane, L.; Gouveia-Caridade, C.; Barsan, M.M.; Baker, P.G.L.; Brett, C.M.A.; Iwuoha, E.I. Electrochemical Determination of Tyrosine using a Novel Tyrosinase Multi-Walled Carbon Nanotube (MWCNT) Polysulfone Modified Glassy Carbon Electrode (GCE). Anal. Lett. 2020, 53, 308-321. [CrossRef]

21. Ghoreishi, S.M.; Behpour, M.; Jafari, N.; Golestaneh, M. Electrochemical Determination of Tyrosine in the Presence of Dopamine and Uric Acid at the Surface of Gold Nanoparticles Modified Carbon Paste Electrode. J. Chin. Chem. Soc. 2012, 59, 1015-1020. [CrossRef]

22. Babaei, A.; Mirzakhani, S.; Khalilzadeh, B. A sensitive simultaneous determination of epinephrine and tyrosine using an iron(III) doped zeolite-modified carbon paste electrode. J. Braz. Chem. Soc. 2009, 20, 1862-1869. [CrossRef]

23. Orhan, H.; Vermeulen, N.P.; Tump, C.; Zappey, H.; Meerman, J.H. Simultaneous determination of tyrosine, phenylalanine and deoxyguanosine oxidation products by liquid chromatography-tandem mass spectrometry as non-invasive biomarkers for oxidative damage. J. Chromatogr. B 2004, 799, 245-254. [CrossRef] [PubMed]

24. Neurauter, G.; Scholl-Burgi, S.; Haara, A.; Geisler, S.; Mayersbach, P.; Schennach, H.; Fuchs, D. Simultaneous measurement of phenylalanine and tyrosine by high performance liquid chromatography (HPLC) with fluorescence detection. Clin. Biochem. 2013, 46, 1848-1851. [CrossRef]

25. Li, S.; Xing, M.; Wang, H.; Zhang, L.; Zhong, Y.; Chen, L. Determination of tryptophan and tyrosine by chemiluminescence based on a luminol-N-bromosuccinimide-ZnS quantum dots system. RSC Adv. 2015, 5, 59286-59291. [CrossRef]

26. Rigobello-Masini, M.; Masini, J.C. Sequential injection chromatography for fluorimetric determination of intracellular amino acids in marine microalgae. In Amino Acid Analysis; Springer: Berlin, Germany, 2012; pp. 305-315.

27. Dailey, C.A.; Garnier, N.; Rubakhin, S.S.; Sweedler, J.V. Automated method for analysis of tryptophan and tyrosine metabolites using capillary electrophoresis with native fluorescence detection. Anal. Bioanal. Chem. 2013, 405, 2451-2459. [CrossRef] [PubMed]

28. Alam, M.M.; Uddin, M.T.; Asiri, A.M.; Rahman, M.M.; Islam, M.A. Detection of L-Tyrosine by electrochemical method based on binary mixed $\mathrm{CdO} / \mathrm{SnO}_{2}$ nanoparticles. Measurement 2020, 163, 107990. [CrossRef]

29. Huang, G.G.; Yang, J. Development of infrared optical sensor for selective detection of tyrosine in biological fluids. Biosens. Bioelectron. 2005, 3, 408-418. [CrossRef]

30. Satheeshkumar, E.; Yang, J. Analyte-induced photoreduction method for visual and colorimetric detection of tyrosine. Anal. Chim. Acta 2015, 879, 111-117. [CrossRef]

31. Karthika, A.; Rosaline, D.R.; Inbanathan, S.S.R.; Suganthi, A.; Rajarajan, M. Fabrication of Cupric oxide decorated $\beta$-cyclodextrin nanocomposite solubilized Nafion as a high performance electrochemical sensor for l-tyrosine detection. J. Phys. Chem. Solids 2020, 136, 109145. [CrossRef]

32. Jin, G.-P.; Lin, X.-Q. The electrochemical behavior and amperometric determination of tyrosine and tryptophan at a glassy carbon electrode modified with butyrylcholine. Electrochem. Commun. 2004, 6, 454-460. [CrossRef]

33. Yola, M.L.; Eren, T.; Atar, N. A sensitive molecular imprinted electrochemical sensor based on gold nanoparticles decorated graphene oxide: Application to selective determination of tyrosine in milk. Sens. Actuators B Chem. 2015, 210, 149-157. [CrossRef]

34. Kavitha, C.; Bramhaiah, K.; John, N.S. Low-cost electrochemical detection of L-tyrosine using an rGO-Cu modified pencil graphite electrode and its surface orientation on a Ag electrode using an ex situ spectroelectrochemical method. RSC Adv. 2020, 10, 22871-22880. [CrossRef]

35. D'Souza, E.S.; Manjunatha, J.G.; Chenthatti, R.; Tigari, G.; Ravishankar, D.K. Rapid Electrochemical Monitoring of Tyrosine by Poly (Riboflavin) Modified Carbon Nanotube Paste Electrode as a Sensitive Sensor and its Applications in Pharmaceutical Samples. Biointerface Res. Appl. Chem. 2021, 11, 14661-14672.

36. Zhang, J. Electrochemical Determination of Tyrosine and Nitrite Using CS/CMWNTs/GCE-modified Electrode. Int. J. Electrochem. Sci. 2018, 13, 3527-3534. [CrossRef]

37. Wang, Y.; Xiong, C.; Qu, H.; Chen, W.; Ma, A.; Zheng, L. Highly sensitive real-time detection of tyrosine based on organic electrochemical transistors with poly-(diallyldimethylammonium chloride), gold nanoparticles and multi-walled carbon nanotubes. $J$. Electroanal. Chem. 2017, 799, 321-326. [CrossRef]

38. Feng, J.; Deng, P.; Xiao, J.; Li, J.; Tian, Y.; Wu, Y.; Liu, J.; Li, G.; He, Q. New voltammetric method for determination of tyrosine in foodstuffs using an oxygen-functionalized multi-walled carbon nanotubes modified acetylene black paste electrode. J. Food Compos. Anal. 2021, 96, 103708. [CrossRef]

39. Liu, M.; Lao, J.; Wang, H.; Xu, Z.; Li, J.; Wen, L.; Yin, Z.; Luo, C.; Peng, H. Electrochemical Determination of Tyrosine Using Graphene and Gold Nanoparticle Composite Modified Glassy Carbon Electrode. Russ. J. Electrochem. 2021, 57, 41-50. [CrossRef] 
40. Kerman, K.; Kraatz, H.-B. Electrochemical detection of protein tyrosine kinase-catalysed phosphorylation using gold nanoparticles. Biosens. Bioelectron. 2009, 24, 1484-1489. [CrossRef] [PubMed]

41. Rasmussen, S. Early History of Polypyrrole: The First Conducting Organic Polymer. Bull. Hist. Chem. Div. Hist. Chem. Am. Chem. Soc. 2015, 40, 45-55.

42. Yussuf, A.; Al-Saleh, M.; Al-Enezi, S.; Abraham, G. Synthesis and Characterization of Conductive Polypyrrole: The Influence of the Oxidants and Monomer on the Electrical, Thermal, and Morphological Properties. Int. J. Polym. Sci. 2018, $2018,1-8$. [CrossRef]

43. Gniadek, M.; Wichowska, A.; Antos-Bielska, M.; Orlowski, P.; Krzyzowska, M.; Donten, M. Synthesis and characterization of polypyrrole and its composites coatings on flexible surface and its antibacterial properties. Synth. Met. 2020, 266, 116430. [CrossRef]

44. Tat'yana, V.V.; Efimov, O.N. Polypyrrole: A conducting polymer; its synthesis, properties and applications. Russ. Chem. Rev. 1997, $66,443$.

45. Geană, E.-I.; Artem, V.; Apetrei, C. Discrimination and classification of wines based on polypyrrole modified screen-printed carbon electrodes coupled with multivariate data analysis. J. Food Compos. Anal. 2021, 96, 103704. [CrossRef]

46. Apetrei, C. Novel method based on polypyrrole-modified sensors and emulsions for the evaluation of bitterness in extra virgin olive oils. Food Res. Int. 2012, 48, 673-680. [CrossRef]

47. Choudhary, M.; Islam, R.U.; Witcomb, M.J.; Mallick, K. In situ generation of a high-performance Pd-polypyrrole composite with multi-functional catalytic properties. Dalton Trans 2014, 43, 6396-6405. [CrossRef] [PubMed]

48. Rezaei, B.; Irannejad, N. Electrochemical detection techniques in biosensor applications. In Electrochemical Biosensors; Elsevier: Amsterdam, The Netherlands, 2019; pp. 11-43.

49. Mortimer, R.J. Spectroelectrochemistry, Applications. In Encyclopedia of Spectroscopy and Spectrometry; Elsevier: Amsterdam, The Netherlands, 2017; pp. 160-171.

50. Oukil, D.; Benhaddad, L.; Aitout, R.; Makhloufi, L.; Pillier, F.; Saidani, B. Electrochemical synthesis of polypyrrole films doped by ferrocyanide ions onto iron substrate: Application in the electroanalytical determination of uric acid. Sens. Actuators B Chem. 2014, 204, 203-210. [CrossRef]

51. Neri, G. First Fifty Years of Chemoresistive Gas Sensors. Chemosensors 2015, 3, 1-20. [CrossRef]

52. Bieńkowski, K.; Strawski, M.; Szklarczyk, M. The determination of the thickness of electrodeposited polymeric films by AFM and electrochemical techniques. J. Electroanal. Chem. 2011, 662, 196-203. [CrossRef]

53. Arrieta, A.A.; Apetrei, C.; Rodríguez-Méndez, M.L.; de Saja, J.A. Voltammetric sensor array based on conducting polymermodified electrodes for the discrimination of liquids. Electrochim. Acta 2004, 49, 4543-4551. [CrossRef]

54. P Gros, H.D.; Comtat, M. Use of polypyrrole film containing Fe (CN) 63- as pseudo-reference electrode: Application for amperometric biosensors. Electrochim. Acta 2001, 46, 643-650. [CrossRef]

55. Apetrei, I.; Apetrei, C. Development of a Novel Biosensor Based on Tyrosinase/Platinum Nanoparticles/Chitosan/Graphene Nanostructured Layer with Applicability in Bioanalysis. Materials 2019, 12, 1009. [CrossRef] [PubMed]

56. Rahman, M.; Lopa, N.S.; Kim, K.; Lee, J.-J. Selective detection of l-tyrosine in the presence of ascorbic acid, dopamine, and uric acid at poly(thionine)-modified glassy carbon electrode. J. Electroanal. Chem. 2015, 754, 87-93. [CrossRef]

57. Wei, Z. Simultaneous Determination of Acetaminophen and Tyrosine Using Screen-printed Electrochemical Sensor Based on MWCNTs-doped Poly(glycine)/Poly(acrylic acid) Conducting Polymers. Int. J. Electrochem. Sci. 2019, 14, 6748-6758. [CrossRef]

58. Taei, M.; Ramazani, G. Simultaneous determination of norepinephrine, acetaminophen and tyrosine by differential pulse voltammetry using Au-nanoparticles/poly(2-amino-2-hydroxymethyl-propane-1,3-diol) film modified glassy carbon electrode. Colloids Surf. B Biointerfaces 2014, 123, 23-32. [CrossRef] [PubMed]

59. Raril, C.; Manjunatha, J.G.; Ravishankar, D.K.; Fattepur, S.; Siddaraju, G.; Nanjundaswamy, L. Validated Electrochemical Method for Simultaneous Resolution of Tyrosine, Uric Acid, and Ascorbic Acid at Polymer Modified Nano-Composite Paste Electrode. Surf. Eng. Appl. Electrochem. 2020, 56, 415-426. [CrossRef]

60. Li, C. Voltammetric determination of tyrosine based on an 1-serine polymer film electrode. Colloids Surf. B Biointerfaces 2006, 50, 147-151. [CrossRef] [PubMed]

61. Turkey, S.; Ermiş, N. Preparation of Molecularly Imprinted Polypyrrole Modified Gold Electrode for Determination of Tyrosine in Biological Samples. Int. J. Electrochem. Sci. 2018, 13, 2286-2298.

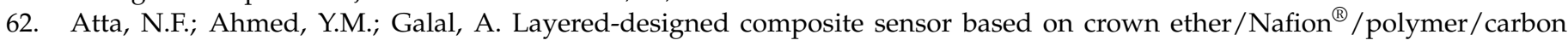
nanotubes for determination of norepinephrine, paracetamol, tyrosine and ascorbic acid in biological fluids. J. Electroanal. Chem. 2018, 828, 11-23. [CrossRef]

63. Roy, S.; Nagabooshanam, S.; Wadhwa, S.; Chauhan, N.; Mathur, A.; Khan, S.A.; Davis, J. Ultra-sensitive detection of l-tyrosine using molecularly imprinted electrochemical sensor towards diabetic foot ulcer detection. Electrochem. Commun. 2020, 117, 106782. [CrossRef]

64. Chen, B.; Zhang, Y.; Lin, L.; Chen, H.; Zhao, M. Au nanoparticles @metal organic framework/polythionine loaded with molecularly imprinted polymer sensor: Preparation, characterization, and electrochemical detection of tyrosine. J. Electroanal. Chem. 2020, 863, 114052. [CrossRef]

65. Ramya, R.; Muthukumaran, P.; Wilson, J. Electron. beam-irradiated polypyrrole decorated with Bovine serum albumin pores: Simultaneous determination of epinephrine and L-tyrosine. Biosens. Bioelectron. 2018, 108, 53-61. [CrossRef] [PubMed] 